\title{
The Impact of Ethical Plans on Job Satisfaction through Perceived Corporate Social Responsibility and Organizational Ethical Environment
}

Parivash Tahmasbi M.A. in Organizational Change Management, Institute for Management and Planning Studies, Tehran, Iran.

Firooz Raznahan ${ }^{1}$ Assistant Professor, Department of Management, Institute for Management and Planning Studies, Tehran, Iran (Corresponding Author).

\begin{abstract}
While the Iranian community is perceived to be a religious and ethical community, the ethical challenges existing in the country's organizations suggest that ethics development cannot be achieved solely through preaching and promotional activities; whereas, it requires the development of a formal organizational ethics system and formal ethics programs. Nowadays, organizations have concluded that in addition to economic attempts (maximizing profits), ethical orientation must be adopted, so that a combination of economic and ethical processes can be their only option for achieving organizational goals. The ethical plans and ethical environment of an organization affect a wide range of organizational, group and individual variables. The purpose of this study is to investigate the impact of organizational ethics programs on job satisfaction through perceived corporate social responsibility and ethical environment. The statistical population of the research were governmental organizations based in Tehran. A sample of 77 governmental organizations was studied using random sampling method and questionnaires. Findings indicate that ethical programs contribute to the development of ethical environment and perceived corporate social responsibility. Ethical environment also enhances the perception of corporate social responsibility and job satisfaction of the employees. Moreover, ethical plans promote the perception of corporate social responsibility through ethical environment. Finally, relevant suggestions for developing ethical plans and strengthening the ethical environment of the organization are presented.
\end{abstract}

Keywords: Ethical Programs, Ethical Environment, Perceived Corporate Social Responsibility, Job Satisfaction, Controlling System.

1. f.raznahan@imps.ac.ir 


\section{مقدمه}

امروزه در شرايط محيطهاى كارى، تغييرهاى فراوانى نسبت به دهلهاى ييشين آخ مىدهند و ماهيت كسبو كارها، تغييرهاى زيادى را تجربه مى كنند (Meriac \& Gorman, 2017). سازمانها براى كاهش هزينهها و يافتن راهكارهاى اثربخش ارائه خدمات و محصولات، تحت فشار هستند و در عين حال، محيطهايى كه سازمانها در آنها فعاليت مى كنند، يِيجيده، يويا، و متغير هستند (Hassan, 2015). در سالهاى اخير، شاهد يروندههاى فساد ادارى و رسوايىهاى مالى فراوانى در مر مانى سازمان ها و شركتهاى دولتى و خصوصى ايران هستيم كه نشانگر آن است كه وجود قوانين و مقررات بلتنهايى براى جلوگيرى از وقوع جنين حوادثى كافى و بازدارنده نيستند و از توسعه و نهادينهسازى سازمانهاى اخلاقى و اخلاق سازمانى در كنار تكيه بر آدمهاى خوب و اخلاقى گريزى نيست. بهطور كلى در كذشته، موفقيت مالى عاملى مهام و تعيين كننده در تعريف سازمان (و شركت) خوب بود. در سالهاى اخير، عواملى مانند ارزشها، اخلاق، كيفيت زندگى كارى، و رضايت شغلى، شاخصهاى

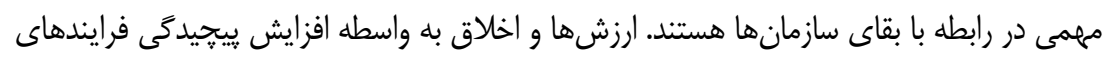
كسبو كار و ضرورت اجراى موثر قوانين اجتماعى، به عاملى راهبردى در حفاظت سازمانها از حوادث

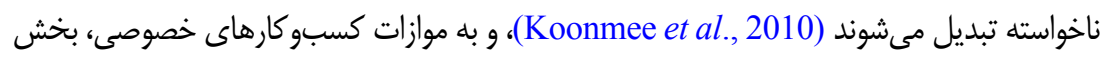
عمومى و دولتى تغييرهاى اساسى بلخود مىبينند. امروزه، به دليل ييامدهاى منفى سياستها و تصميمها، سازمانهاى عمومى و خصوصى بر ابعاد فرهنگىى، اجتماعى، اخلاقى، زيستمحيطى، و و

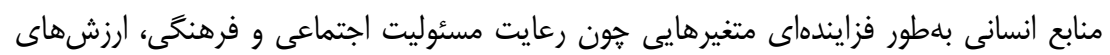
مذهبى، و اصول اخلاقى را در عرصه خطمشى گذارى و مديريت عمومى كشور مورد توجه قرار مىدهند. در نتيجه، سازمانها و مديران دريافتهاند كه علاوه بر رفتارهاى وظيفهاى و اقتصادى

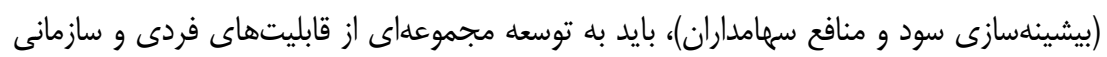
همجون رفتارهاى اخلاقى، مسئوليت اجتماعى، و فرهنگى بيردازند. از اينرو، اثربخشى وظيفهاى،

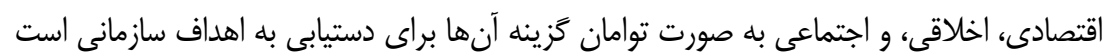

.(Koh \& El'fred, 2004) بر اساس نظريه ناهماهنخى شناختى'، محيط اخلاقى سازمان باعث كاهش تعارض و افزايش 
رضايت شغلى كاركنان مىشود (Viswesvaran et al., 1998). رضايت شغلى با نظامهاى تقويت و

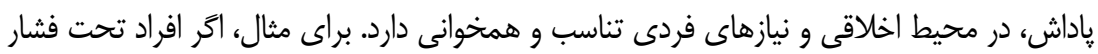

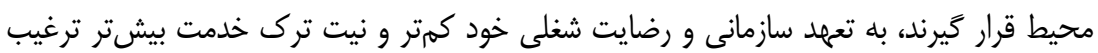
مىشوند (Shafer, 2015). محيط اخلاقى يكى از مهمترين عوامل موثر بر ميزان رضايتمندى و

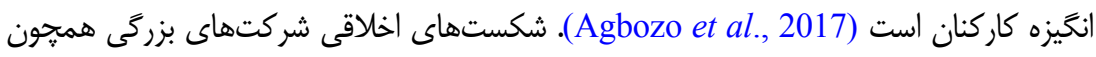

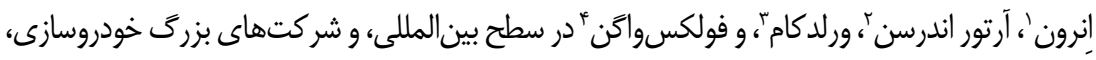

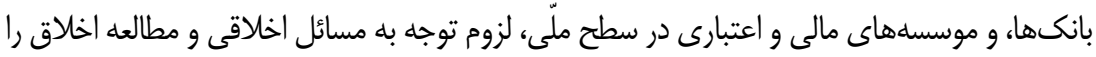
در حوزه كسبوكارها بيش از ييش برجسته مى كنند. برنامههاى اخلاقى توسط اسناد اخلاقى رسمى

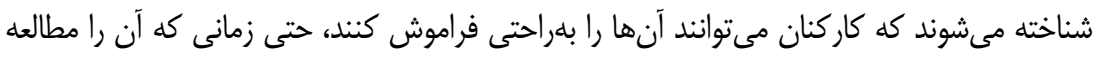

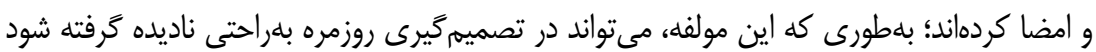

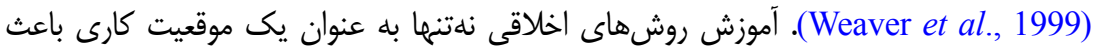

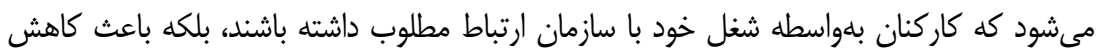
تعارض اخلاقى مى شود (Valentine \& Fleischman, 2008a). يزوهشهاى اندكى، اثرهاى

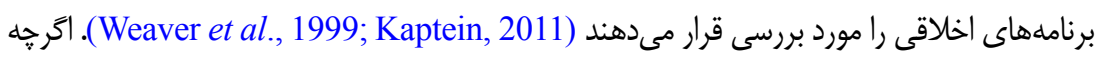
بسيارى از سازمانها، داراى برنامههاى اخلاقى هستند، ولى به تاثير واقعى آنها بر نكرش و ورفار رفتار

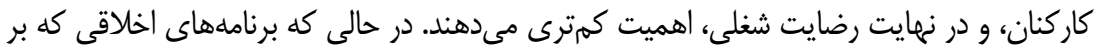
ارزشكذارى، كنترل، نظه و انضباط، و مسئوليتيذيرى بيشترى تاكيد دارند، رفتارهاى غير اخلاقى رادر سازمانها كاهش مىدهند (Weaver \& Trevino, 1999). به مرور زمان، بيشتر سازمانها تلاش

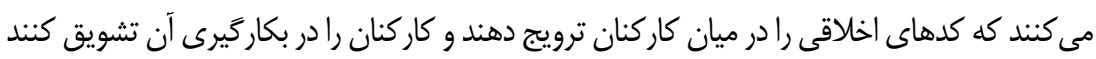

.(Ruiz et al., 2015)

مسئوليت اجتماعى سازمان، به عنوان يك روند جهانى ظهور كردهاست (Asrar-ul-Haq etal., 2017). در بيشتر يزوهشها، مسئوليت اجتماعى سازمان مورد تاكيد قرار مى گيرد. اگرَهه مسئوليت اجتماعى بلهور كَتردهاى در عرصه اجتماعى استفاده مىشود و مورد نياز تمام سازمانهاست، اما بسيارى از سازمانهاى فعال در عرضه كسبوكار ادعا دارند كه درى مسئوليت اجتماعى بيش از حد مبهرم و بلهور بالقوه يرهزينه است (Kakabadse \& Rozuel, 2006). مسئوليت اجتماعى سازمان كمترين

1. Enron

2. Arthur Anderson

3. World Com

4. VolksWagen 
تعهد در حل مشكلات جامعه است، و نهتنها مىتواند روابط با ذىنفعان و عموم مردم را تقويت كند،

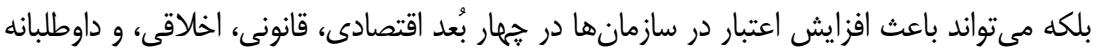
شود (Crespo \& Del Bosque, 2005). بنابراين، مسئوليت اجتماعى سازمان بايد به عنوان يك

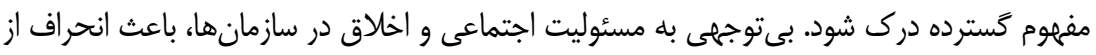
اهداف، منافع، و نيازهاى سازمانى مى شود (Vlachos et al., 2009). با توجه به اين تغييرها، اخلاق اهميت زيادى ييدا مى كند و در ييشيينى بسيارى از متغيرهاى سازمانى و رفتارى نقش مهمى دارد

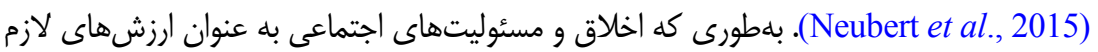
براى موفقيت كسبوكار مورد تاكيد قرار مى گيرند (Halinen \& Jokela, 2016). بلطور كلى، در تبيين اهميت اين يزوهش بايد كفت كه يرداختن به حفظ و ترويج ارزشهاى اخلاقى در سازمان از يك سو بر كنش و واكنشهاى سازمانى، و از سوى ديخر، بر كارايى و اثربخشى سازمانى تاثير مى كذارند. به دليل اهميت ماهوى هر يك از سه مولفه اخلاق، مسئوليت اجتماعى، و رضايت شغلى، دائ

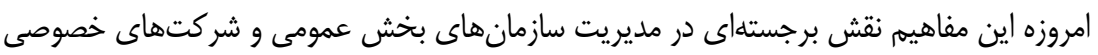

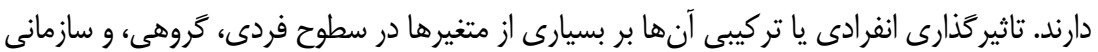

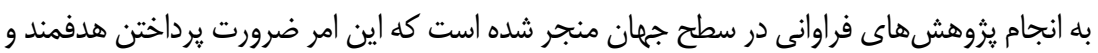

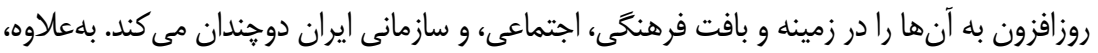

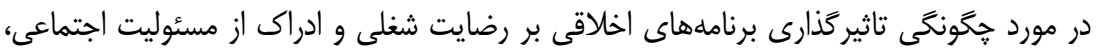

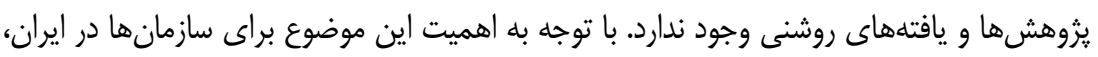
بلويزه براى بخش دولتى و عمومى، يزوهش حاضر درصدد ارائه ياسخهايى براى شكافهاى يان يادشده

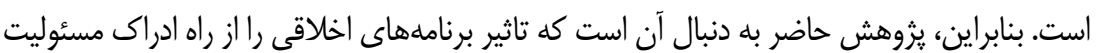

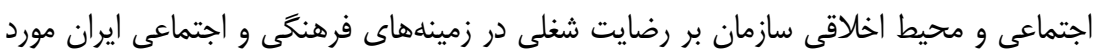

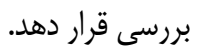

\section{مبانى نظرى و بيشينهُ بزووهش}

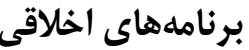

برنامههاى اخلاقى به عنوان برنامههاى رسمى تعريف مى شوند (Kaptein, 2009). يعنى با قصد

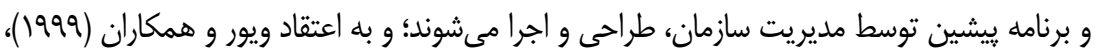

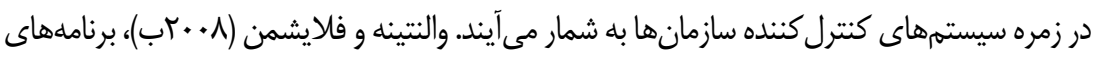


اخلاقى را شامل كدهاى اخلاقى، ارائه كدهاى اخلاقى، آموزشهاى كدهاى اخلاقى، و ساعت آموزش

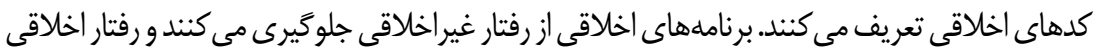

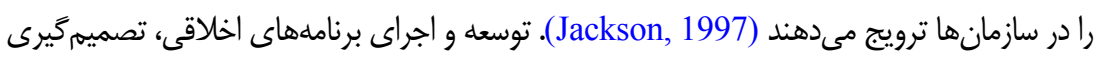
اخلاقى را در محيطهاى كارى ارتقامىدهند (Ruiz et al., 2015). برنامههاى اخلاقى، رويكردهايى برايى

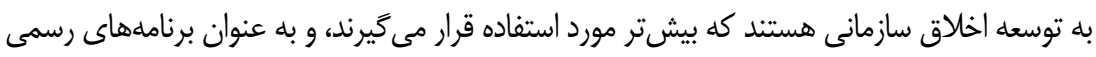

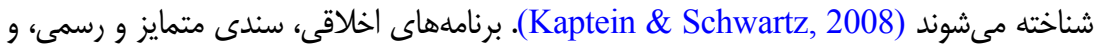

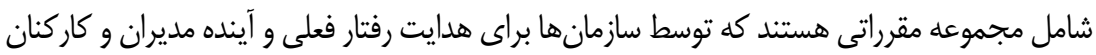
نسبت به مسائل متعدد ايجاد مى شوند كه ممكن است براى سهامداران خارجى يا سازمان ها نسبت بهان

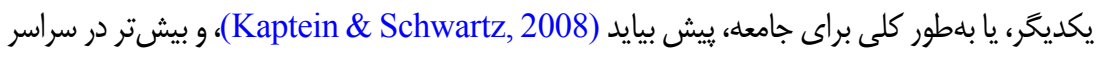

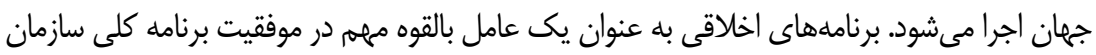
نقش ايفامى كنند (Ruiz et al., 2015)، و براى ارتقاى تصميمَّيرى اخلاقى مورد توجه قرار مى كيرند.

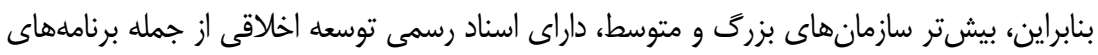

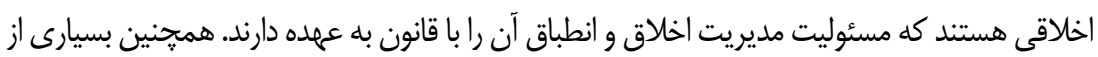

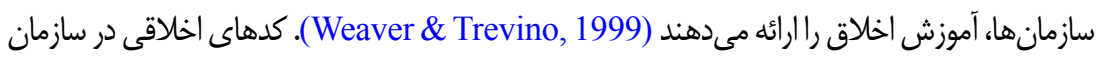

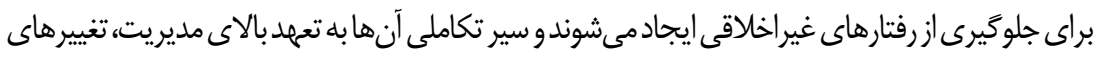

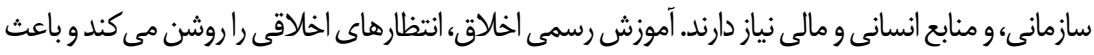
افزايش مهارتها و عمل به تعهد مديران و كاركنان مىشود (Valentine \& Fleischman, 2004).

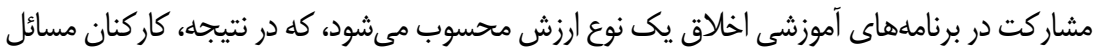

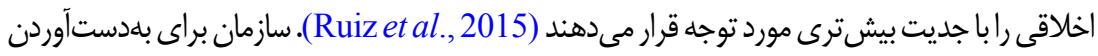

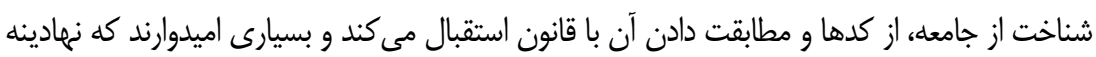

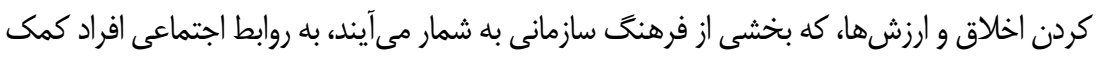

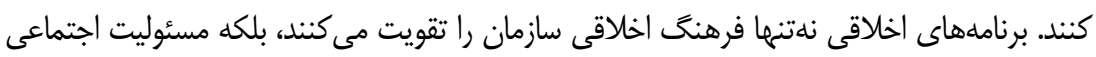

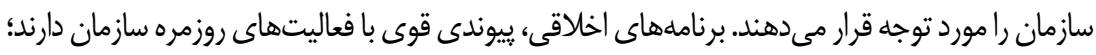

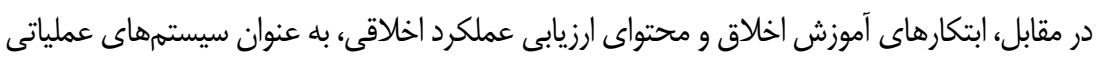

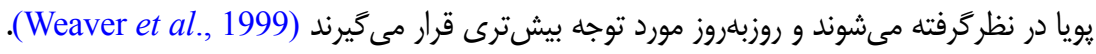

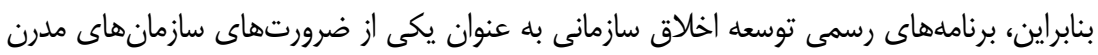
قلمداد مىشوند. 


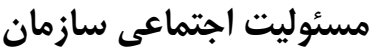

مسئوليت اجتماعى سازمان، مفهومى است كه هيج تعريف يذيرفتهشده يكانهاى كه مورد يذيرش همكان باشد، ندارد (Asrar-ul-Haq et al., 2017). مسئوليت اجتماعى سازمان به معناى

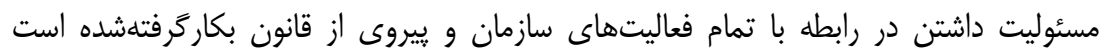
(Arnaudov \& Koseska, 2012). مسئوليت اجتماعى سازمان شامل انتظارهاى اقتصادى، قانونى، اخلاقى، و بشردوستانهاى است كه جامعه در يك زمان معين از سازمان توقع دارد .(Mandhachitara \& Poolthong, 2011; Branco \& Rodrigues, 2006; Carroll, 1979) مسئوليت اجتماعى سازمان يعنى مسئول بودن سازمان در برابر محيط كه فراتر از تعهدهاى قانونى

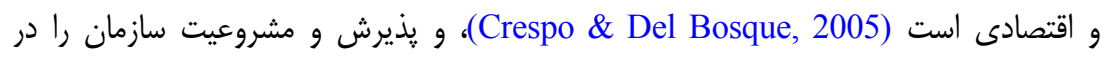

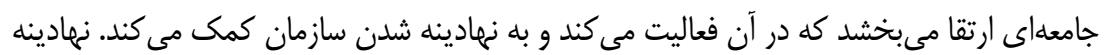
شدن يعنى تداوم بقا و عمر طولانى يك سازمان به عنوان بخشى كاركردى و لازم از يك جامعله، كه بالاترين اهميت را براى سازمان دارد.

\section{رضايت شغلى}

از رضايت شغلى تعاريف متعددى ارائه شده است؛ رضايت شغلى را مىتوان حالت عاطفى

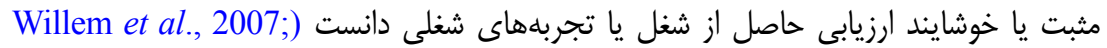
(Lu et al., 2007; Yang \& Chang, 2008 و جلوههاى شغلى، و قضاوت مثبت يا منفى فرد در مورد شغل يا موقعيت شغلى خود تعريف مىشود (Daehlen, 2008; Herrbach \& Mignonac, 2007). وقتى رضايت شغلى به عنوان يك نخرش تعريف شود، مىتواند ارزيابى يا قضاوتى مثبت (يا منفى) باشد كه شخص درباره شغل يا شرايطى شغلى خود دارد. احساسات، بلهطور جدايىنايذيرى با جنين ارزيابىهايى مرتبط هستند،

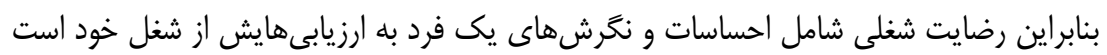

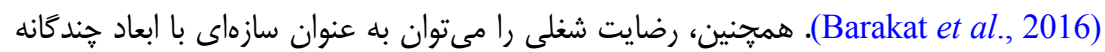

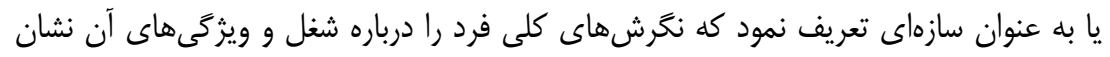

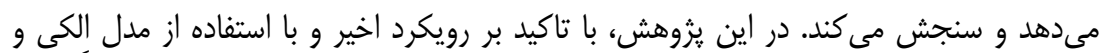

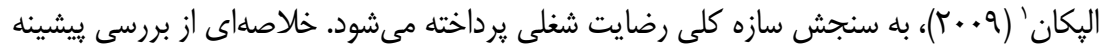




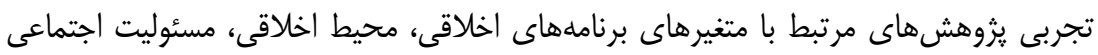

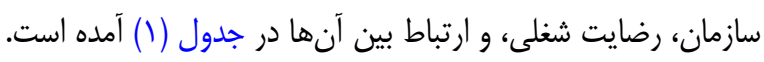

\section{برنامههاى اخلاقى و تأثيرهاى آن بر كار كنان}

والنتينه و بارنت' (T +.؟)، بيان مى كنند كه بيشتر سازمان ها، برنامههاى اخلاقى را مىيذيرند؛

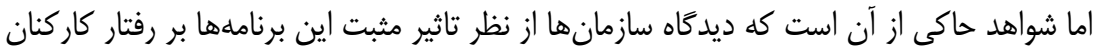

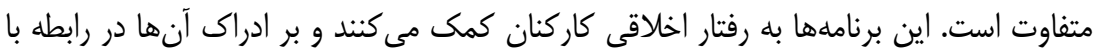

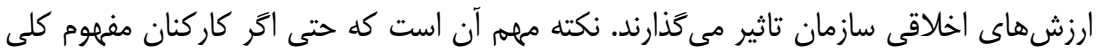

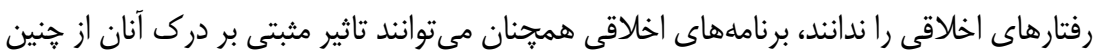

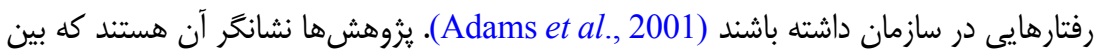

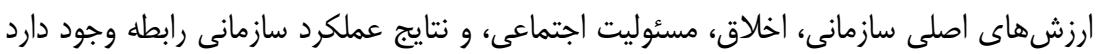
.(Jin \& Drozdenko, 2010; Jin et al., 2013)

\section{برنامههاى رسمى اخلاقى و رضايت شغلى}

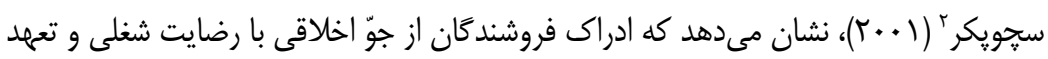
سازمانى رابطه مثبت دارد. جوّ اخلاقى، رابطه مثبتى با رضايت شغلى فروشندكان و تعهد سازمانى، و رابطؤ منفى با قصد ترك خدمت دارد. علاوه بر اين، رضايت شغلى رابطه مثبتى با تعهد سازمانى إنى

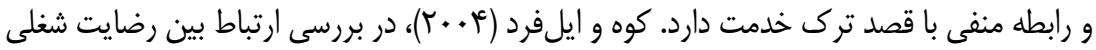
و اخلاق سازمانى دريافتند كه بين اخلاق سازمانى و رضايت شغلى رابطه وجود دارد؛ و مديران إنان

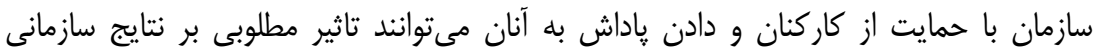

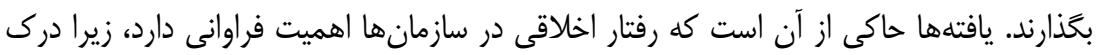
مديران را از عواملى افزايش مىدهد كه در ارتباط با اخلاق سازمانى و تصميمَّيرى اخلاقى است التان.

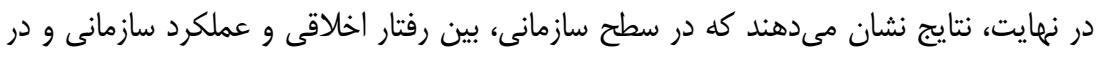
سطح فردى، بين رفتارهاى اخلاقى كاركنان با رضايت شغلى، استرس، انغيزش، تعهل، عملكرد،

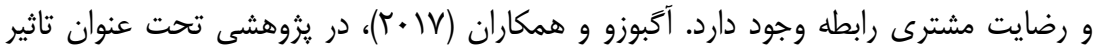

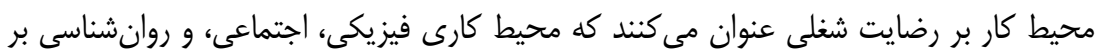

1. Valentine \& Barnett

2. Schwepker 
رضايت شغلى تاثير مى كذارند و يافتههاى اين يثوهش بر نياز به مديريت كردن محيط كارى با هدف بهبود محيط كارى كاركنان براى افزايش بهرهورى تاكيد مى كند. اسرارالحق و همكاران

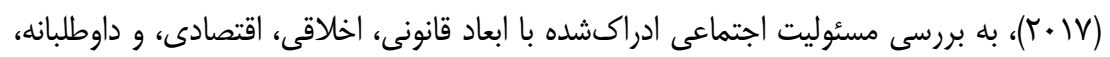

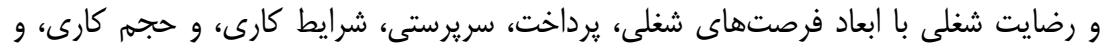

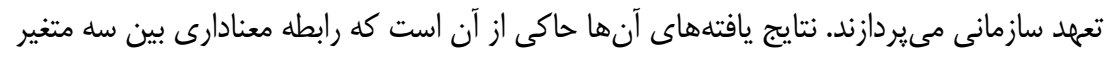
ادراك از مسئوليت اجتماعى، رضايت شغلى، و تعهد سازمانى وجود دارد. در بين ابعاد مسئوليت

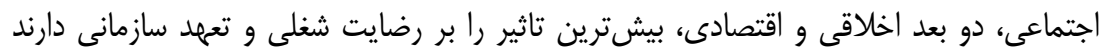

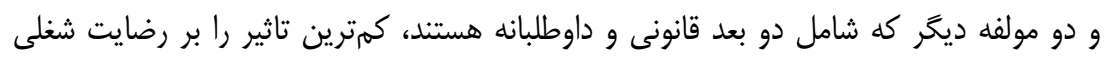

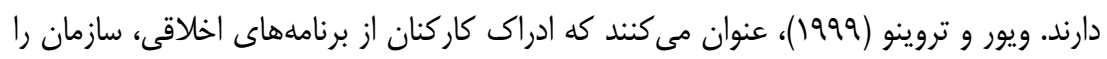

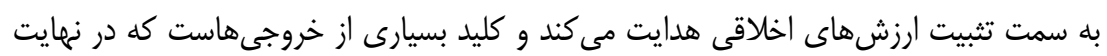
به رضايت شغلى كاركنان منجر مىشود. نادى و حاذقى (.وس"ا)، بيان مى كنند كه جوّ اخلاقى بر

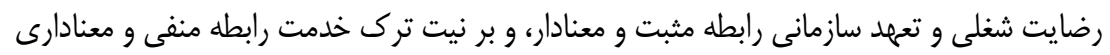
دارد. همجنين، با افزايش رضايت شغلى، تعهد سازمانى افزايش، و نيت ترك خدمت كاهش رابط مىيابد، و تعهد سازمانى بر نيت ترك خدمت رابطه منفى و معنادارى دارد. مدل معادله ساختارى،

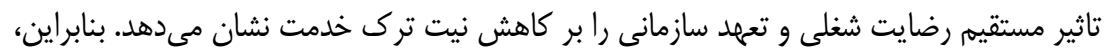
يزوهشهاى متعدد نشانكر آن هستند كه بين برنامههاى رسمى اخلاقى و رضايت شغلى ارتباط

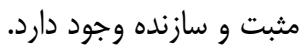

جدول 1: يِيشه تجربى متغيرهاى يزوهش

يُزوهشخر (ان) جمع آورى داده

بين جهار سازه ارزش هاى سازمانى، اخلاق،

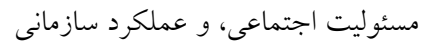

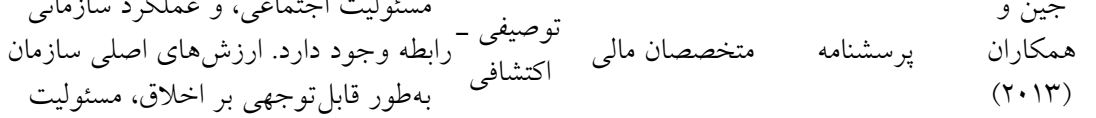

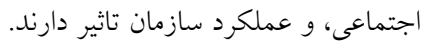

$$
\begin{aligned}
& \text { اخلاق حرفهاى تحت تاثير مسئوليت }
\end{aligned}
$$

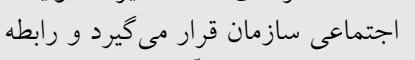

$$
\begin{aligned}
& \text { مثبتى با آن دارد. } \\
& \text { يرسشنه } \\
& \text { والنتينه و } \\
& \text { فلايشمن والنينه } \\
& \text { (ب..人) }
\end{aligned}
$$


ادامه جدول ا: ييشينه تجربى متغيرهاى يزوهش

\begin{tabular}{|c|c|c|c|c|}
\hline يافته ها & بثروهش روش & جامعه و نمونه & جمع آورى دوش داده & يزوهشخر (ان) \\
\hline 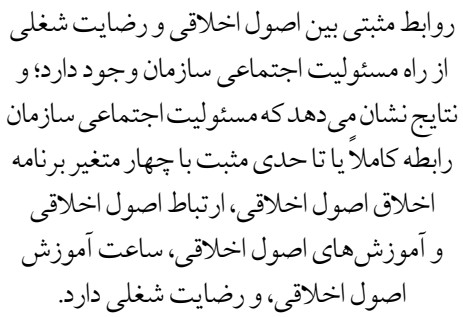 & ـ توصيفى اكتشافى & كتخصع مسان نفر از & ير سشنامه & 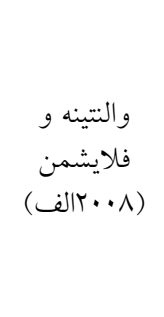 \\
\hline
\end{tabular}

كاركنان در سازمانهاى رسمى كه داراى

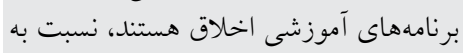

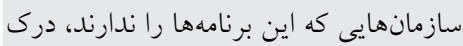

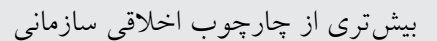

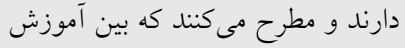

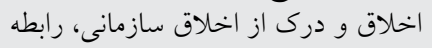

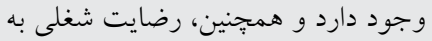

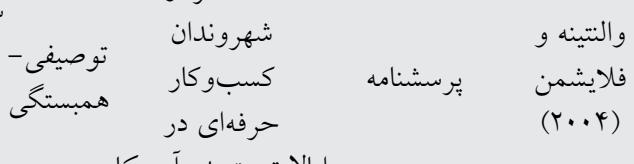
نغرش كارمندان وابسته است وضن

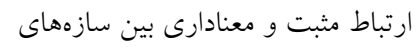

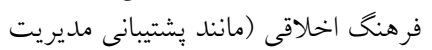

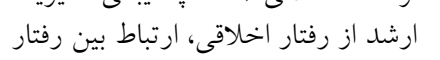

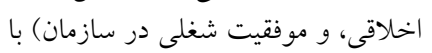
رضايت شغلى وجود دارد.

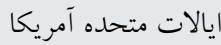

باس نقر از

-

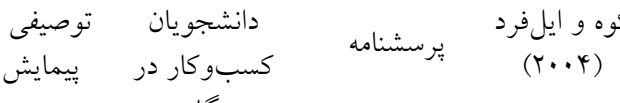
سنخايور

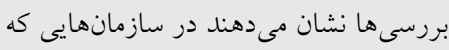

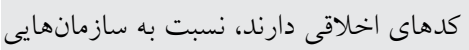

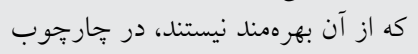
سازمانى خود از رفتار اخلاقى كاركنان حمايت بيشترى مى كنند.

$$
\text { سم شركت }
$$

نتايج نشان مى دهند كه ادراى فروشند كان از جوّ اخلاقى با رضايت شغلى و تعهد سازمانى رابطه مثبت دارد.

$$
\begin{aligned}
& \text { (نمونه و9تايى) }
\end{aligned}
$$

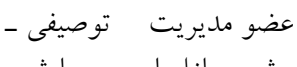

$$
\begin{aligned}
& \text { فروش و بازاريابى ييمايش } \\
& \text { سجويكر } \\
& \text { در جنوب ايالات } \\
& \text { متحده آمريكا }
\end{aligned}
$$

بين ادراك رفتارهاى اخلاقى مديران با تمام

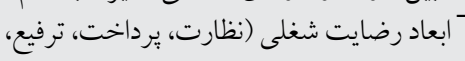

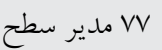


ادامه جدول 1: بيشينه تجربى متغير هاى يُووهش

\begin{tabular}{|c|c|c|c|}
\hline يُخوهش روش & جامعه و نمونه & جمع آورى دوش داده & بزوهشخر (ان) \\
\hline 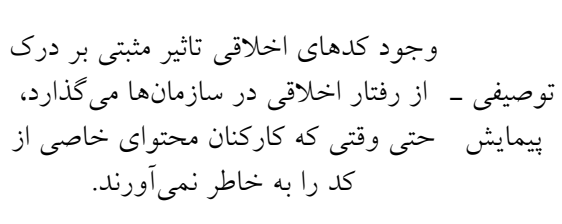 & 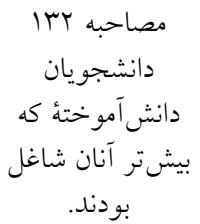 & و و مصاحسبه & 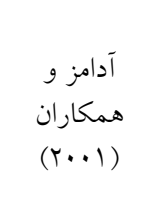 \\
\hline
\end{tabular}

\section{برنامههاى رسمى اخلاقى و مسئوليت اجتماعى}

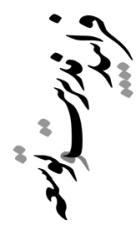

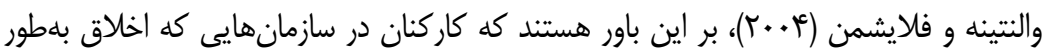
رسمى آموزش داده مىشود، در مقايسه با سازمانهايى كه از اين برنامهها از جمله آموزش اخلاق بهرهمند نيستند، درى بيشترى از هارجوب اخلاقى سازمانى دارند؛ در نتيجه، بين آموزش اخلاق و درك از اخلاق سازمانى رابطه وجود دارد. والنتينه و فلايشمن (1 +. آالف)، نشان مى دهند كه مسئوليت اجتماعى سازمان و برنامههاى اخلاقى (شامل تهرار متغير كدهاى اخلاقى، ارائه كدهاى اخلاقى،

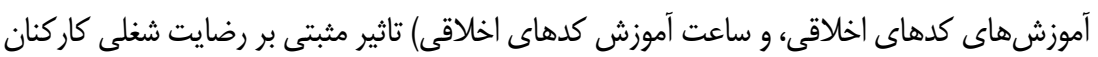
دارند. در واقع، سازمانها با ارائه برنامههاى آموزش اخلاقى، رفتار اخلاقى كاركنان و نخرشهاى

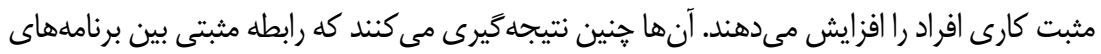

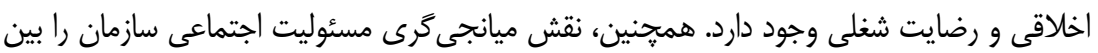
برنامههاى اخلاقى و رضايت شغلى كاركنان تاييد مى كنند. والنتينه و فلايشمن (1 +. باب)، بيان مى كنند كه اخلاق حرفهاى تحت تاثير مسئوليت اجتماعى سازمان قرار مى گيرد و رابطه مثبتى با آن دارد، و نخرش اخلاقى با فعاليتهاى سازمان در ارتباط است. با توسعه اخلاق حرفهاى در سازمان، رفتار

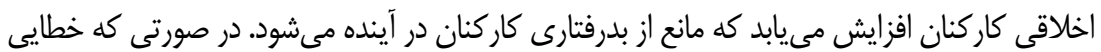
در رفتار اخلاقى اخ دهد، اعتبار تمام حرفه يا شغل در معرض خطر قرار مى ميرد. سازمانها بايد ارتباط بين استانداردهاى اخلاقى حرفهاى و اخلاق سازمانى و مسئوليت اجتماعى را تقويت كنند. اين يافتهها نشان مى دهند كه سازمان ها ممكن است نخرش اخلاقى كاركنان را از راه مسئوليت اجتماعى سازمان بهتر توسعd دهند. براكت و همكاران (عاء (Y)، عنوان مى كنند كه مسئوليت اجتماعى سازمان بر رضايت شغلى تاثير مثبت دارد. ابزارى و يزدانشناس (عیىا)، در بررسى رابطه مسئوليت اجتماعى و اخلاق كار مهار 
در مديريت كيفيت نوين بيان مى كنند كه بين اخلاق كار و مسئوليت اجتماعى سازمان رابطه تنكاتنكى

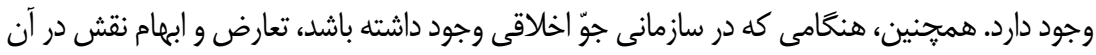
سازمان، كمتر و در نتيجه، رضايت شغلى بالاترى را نشان مىدهد، كه اين امر به نوبه خود باعث كاهش قصد ترك خدمت و تعهد سازمانى مىشود (Jaramillo et al., 2006). بنابراين، بررسى يِيشينه

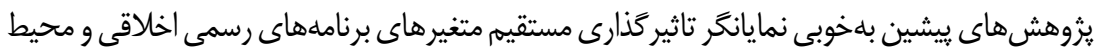

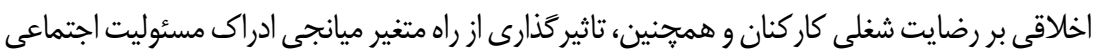

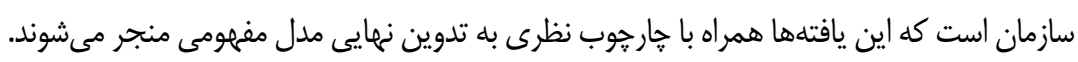

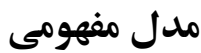

مدل يزوهش شامل دو متغير مستقل محيط اخلاقى و برنامه اخلاقى است. برنامههاى اخلاقى

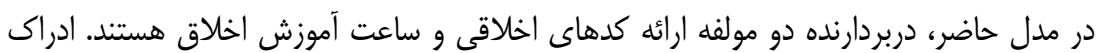

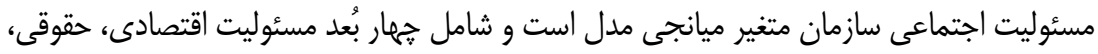

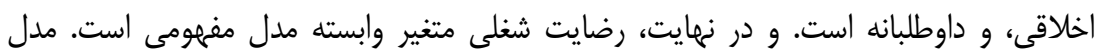
مفهومى يزوهش در شكل (1) آمده است:

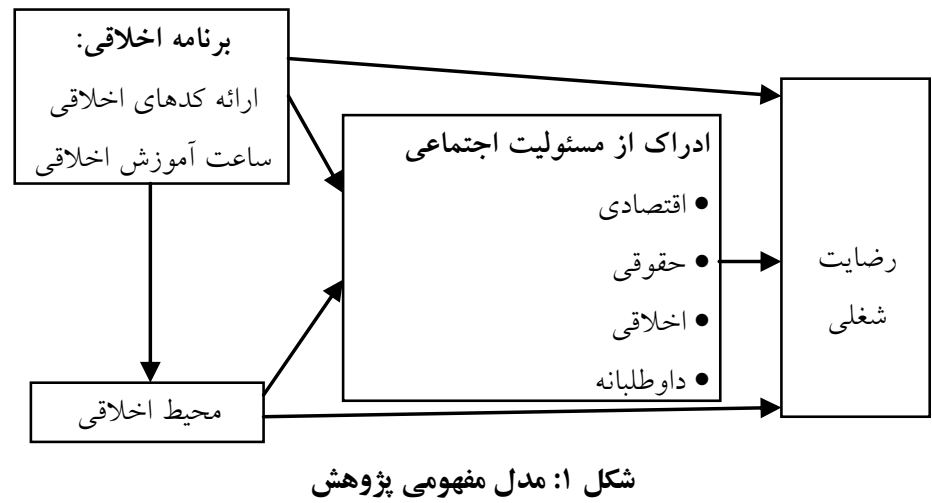

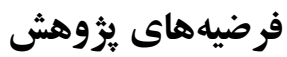

با توجه به مدل مفهومى، فرضيههاى يزوهش تبيين مىشوند: فرضيه ا: برنامه اخلاقى بر محيط اخلاقى تاثير مثبت دارد. 
فرضيه ז: برنامه اخلاقى بر ادراك از مسئوليت اجتماعى تأثير مثبت دارد.

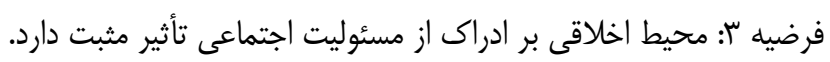

فرضيه f: محيط اخلاقى بر رضايت شغلى تأثير مثبت دارد.

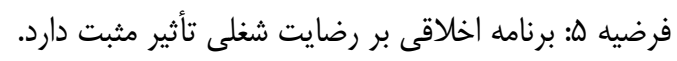

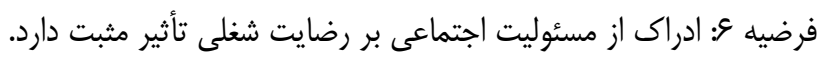

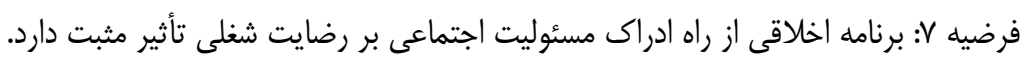

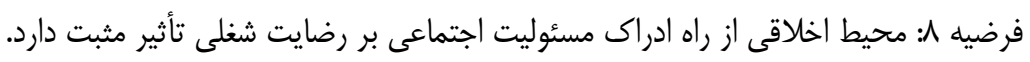

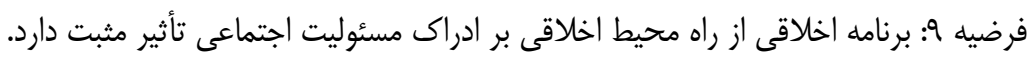

\section{روش ثيزوهش}

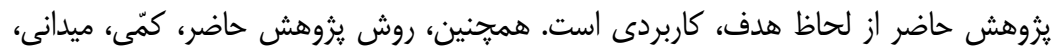

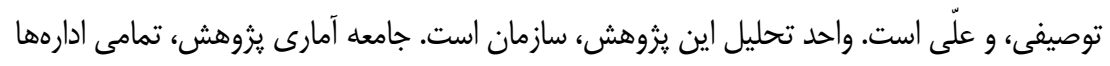

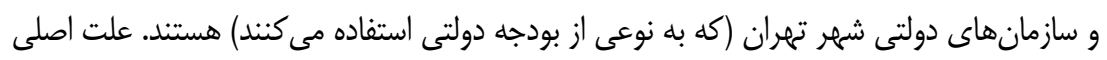

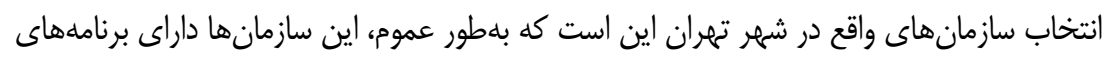

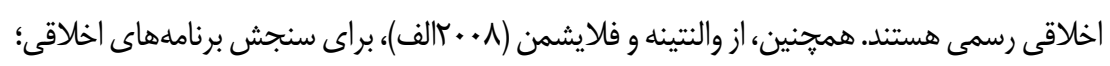

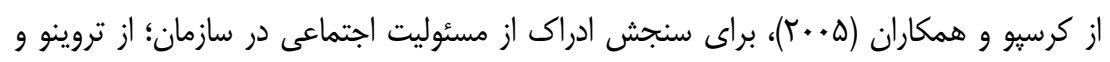

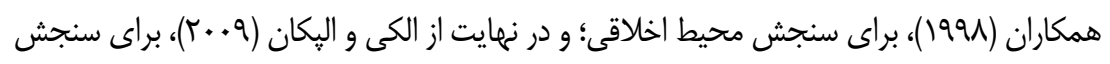

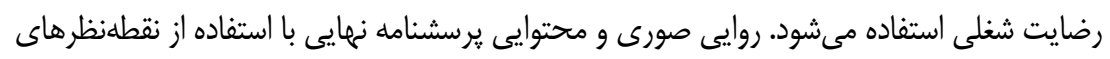

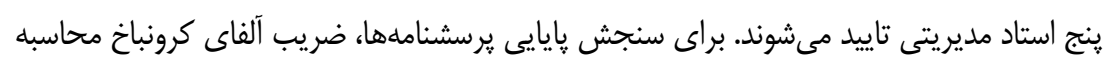

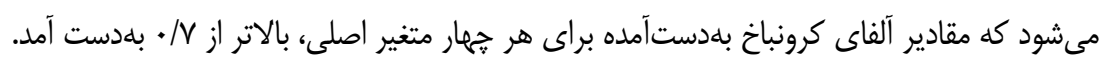

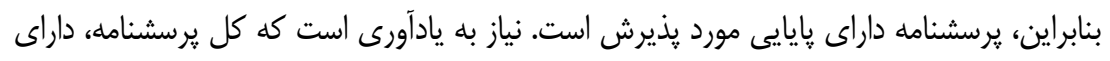

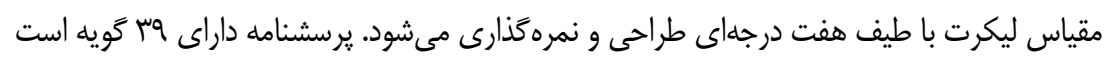

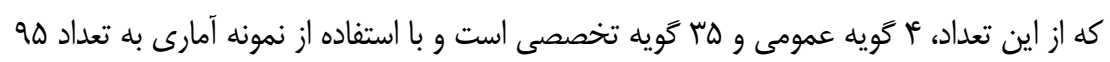

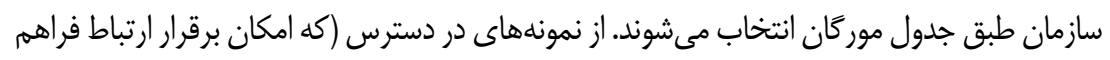

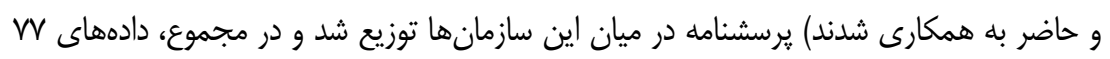
سازمان تحليل شدند. در جدول (Y)، اسامى سازمانهاى مورد مطالعه آورده شده است. 
جدول ז: اسامى سازمانهاى مورد مطالعه

\begin{tabular}{|c|c|c|c|c|c|}
\hline 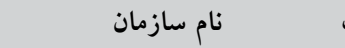 & رديف - & 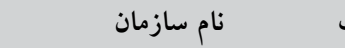 & 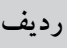 & 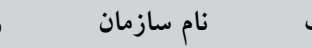 & 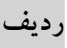 \\
\hline معاونت امور اجتماعى و فرهنگى & or & دانشكده علوم تربيتى و روانشناسى & TV & سازمان سنجش آموزش كشور & 1 \\
\hline روزنامه رسمى كشور & or & دانشكده علوم زيستى & r^ & سازمان تربيت بلدنى & r \\
\hline اداره كل ورزش و جوانان & $\Delta \Delta$ & دانشكده ادبيات و زبان و تاريخ & rq & سازمان تبليغات اسلامى & r \\
\hline دفتر امور مشترك فلدراسيون & DG & دانشكده هنر & r. & سازمان فرهنگ و ارتباطات & Y \\
\hline وزارت صنعت، معدن، و تجارت & $\Delta V$ & دانشكده مطالعات زنان & M & سازمان حج و زيارت & $\Delta$ \\
\hline اداره كل امور ماليات & $\Delta \wedge$ & دانشكده تربيت بلدى و علوم ورزشى & ret & سازمان تعزيرات اجراى احكام & 4 \\
\hline اداره ثبت احوال & Q৭ & دانشكده علوم اجتماعى و اقتصاد & 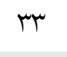 & سازمان حسابرسى & V \\
\hline اداره كل راهدارى حملونقل & 9. & دانشكده فنى مهندسى & ry & سازمان اوقاف و امور خيريه & $\wedge$ \\
\hline شركت ملّى كَاز ايران & 4) & دانشكده فيزيك & ra & سازمانميراثفرهنكى گردشخرى & 9 \\
\hline اداره برق & st & آموزش و يرورش & re & سازمان امور اراضى كشور & 1 . \\
\hline شركت تعاونى مصرف فنى و & st & موسسه آموزش عالى مديريت و & re & 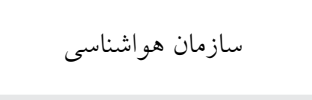 & 11 \\
\hline كميته امداد & sq & اداره كل آموزش فنى و حرفهاى & ra & سازمان خبر گزارى & ir \\
\hline جمعيت هلال احمر & 90 & بيمارستان امام خمينى & rq & سازمان جهاد كشاورزى & ir \\
\hline اداره يُست & 99 & بيمارستان آيتالله طالقانى & f. & سازمان تعاون روستايى & 14 \\
\hline بنياد شهيد & $9 V$ & بيمارستان طرفه & +1 & مصرف كنند مازمان حمايت از توليدكنندگان & 10 \\
\hline 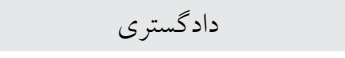 & $9 \wedge$ & 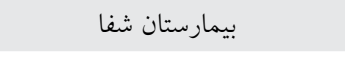 & et & سازمان جابِ و انتشار & 19 \\
\hline 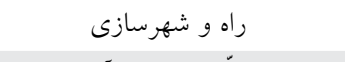 & 99 & بيمارستان ابنسينا & pr & وزارت امور اقتصادى و داريى & IV \\
\hline شركت ملّى يخش فر آوردههاى & V. & شبكه بهداشت و درمان & FY & & 11 \\
\hline فرماندارى تهران & v) & اورزانس & id & بانك رفاه كارگران & 19 \\
\hline منابع طبيعى و آبخيزدارى & VY & وزارت فرهنگ و ارشاد اسلامى & 49 & بانكى مركزى & r. \\
\hline اداره منابع آب & 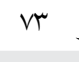 & اداره تبليغات جشنواره فيلم فجر & \&V & بانك مسكن & rI \\
\hline آب و فاضلاب & $v^{f}$ & مجتمع فرهنَى و هنرى & $\psi \wedge$ & بانكى كشاورزى & Tr \\
\hline اداره ثبت اسناد & $\vee Q$ & كتابخانههاى عمومى & 49 & بانك سيه & M \\
\hline اداره كل امور اجرايى & VQ & مركز توسعه فناورى اطلاعات و & $\omega$ & دانشكده الهيات دانشخاه تهران & YY \\
\hline محيطزيست & V & موسسه انتشار ات اميركبير & 01 & دانشكده شيمى & ro \\
\hline & - & كانون فرهنكى & or & دانشكده علوم رياضى & rQ \\
\hline
\end{tabular}




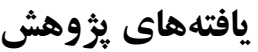

از آنجايى كه از يرسشنامهاى داراى روايى و ويايايى مناسب براى سنجش متغيرها استفاده

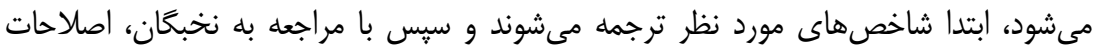

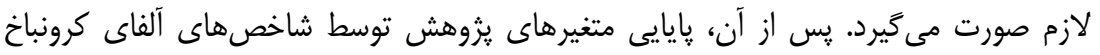

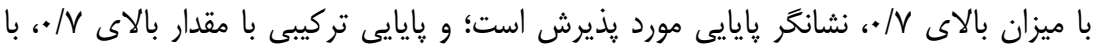

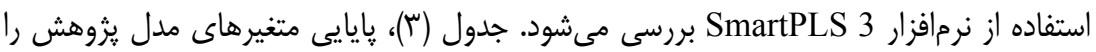

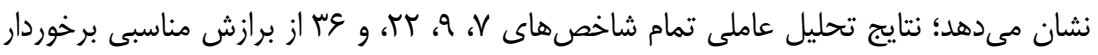

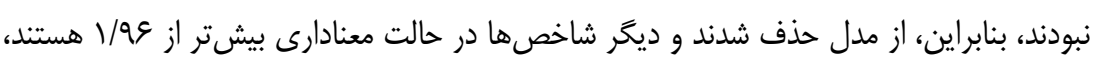

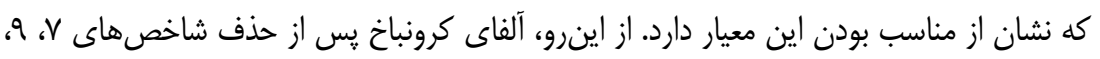

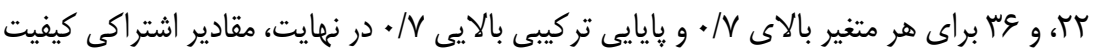

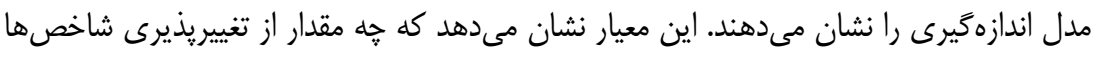

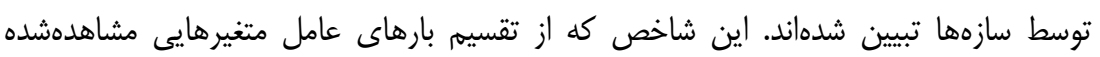

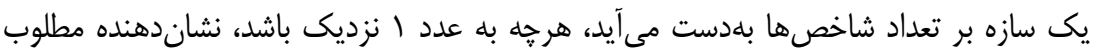

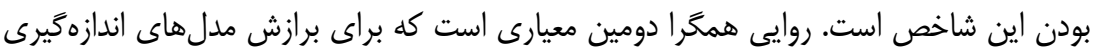

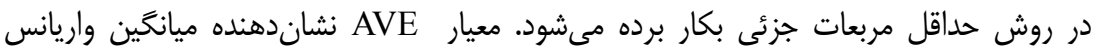

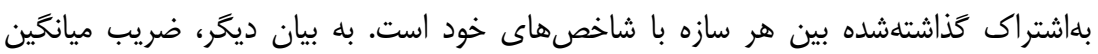

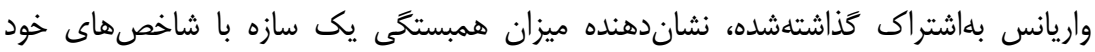

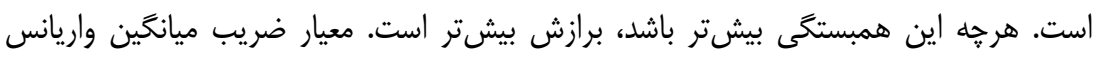

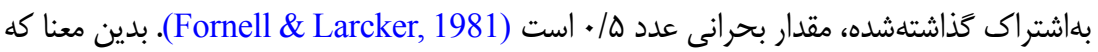

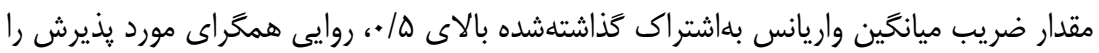

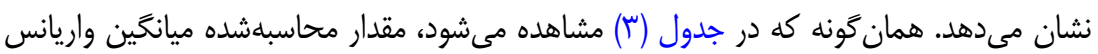
بهاشتراك كذاشتهشده براى هر جهار سازه از مقدار بحرانى هـ • بالاتر است؛ بنابراين، روايى همكرا

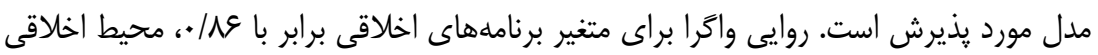

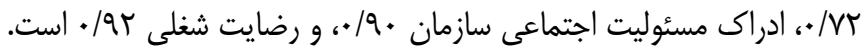


جدول rا: يايايى شاخصهاى بهدست آمده از خروجى نرمافزار PLS

\begin{tabular}{|c|c|c|c|c|c|c|}
\hline وائى & همخرا & تر بايبى & كرونباخ & بار عاملح & شاخص ها & متغيرها \\
\hline$\cdot / 19$ & $\cdot / V^{k}$ & $\cdot / \Lambda \Delta$ & •/Vq & $\begin{array}{l}\cdot / 149 \\
\cdot / 199\end{array}$ & ساعت آموزش اخلاقى كدائ اخداى اخلاقى & $\begin{array}{l}3 \\
\dot{3} \\
3 \\
3 \\
3 \\
y\end{array}$ \\
\hline . /VY & •/OT & $\cdot / M \Lambda$ & $\cdot / 19$ & $\begin{array}{l}\cdot / \mathrm{VQ} \\
\cdot / 19 \\
\cdot / 19 \\
\cdot / 19 \\
\cdot / \Lambda 1 \\
\cdot / \mathrm{NV} \\
\cdot / \mathrm{VA} \\
\cdot / 4 Q \\
\cdot / \mathrm{AY} \\
\cdot / Q Y \\
-\cdot / 4 \mathrm{~V} \\
-\cdot / 9 Q\end{array}$ & 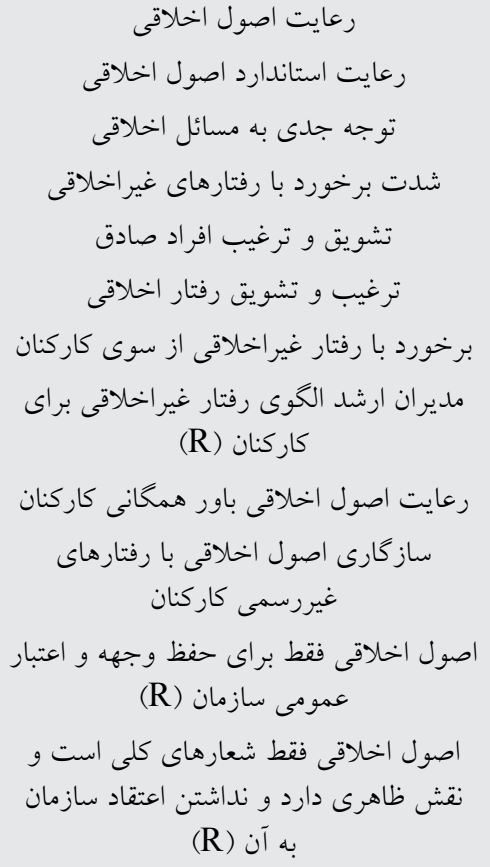 & $\frac{a^{3}}{\frac{1}{1}}$ \\
\hline$\cdot / 9 \cdot$ & $\cdot / \cdot \wedge r$ &.$/ 90$ & $\cdot / 94^{c}$ & $\begin{array}{l}\cdot / 94 \\
\cdot / 94 \\
\cdot / 91 \\
\cdot 119\end{array}$ & مسئم مسئوليت اقتصادى مقوليت اخلاقى & $\begin{array}{ll}\overline{7} & \overline{1} \\
\overline{5} & 3 \\
3 & 4 \\
3 & 3 \\
3 & 3 \\
3 & 3\end{array}$ \\
\hline$\cdot / 9 T$ & •/^९ & $\cdot / 90$ & . $/ 94$ & $\begin{array}{l}. / 9 \\
. / 90 \\
. / 94\end{array}$ & بهلمور كلى رضايت موفقيت در شغل شغل & $\begin{array}{l}3 \\
3 \\
3 \\
3 \\
3 \\
3\end{array}$ \\
\hline
\end{tabular}




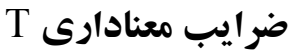

ابتدايىترين معيار براى سنجش، رابطه بين سازههاست؛ در صورتى كه مقدار عدد معنادارى بيشتر

از צو/ باشد، فرضيههاى يثوهش تاييد مى شوند. يادآورى اين نكته ضرورى است كه عدد معنادارى

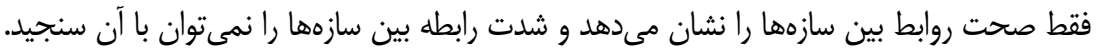
نمودار (()، نشان دهنده اعداد معنادارى است. مطابق با اين نمودار، اعداد معنادارى مربوط بهان مسيرهاى

برنامههاى اخلاقى بر رضايت شغلى و ادراك مسئوليت اجتماعى بر رضايت شغلى معنادار نيستند.
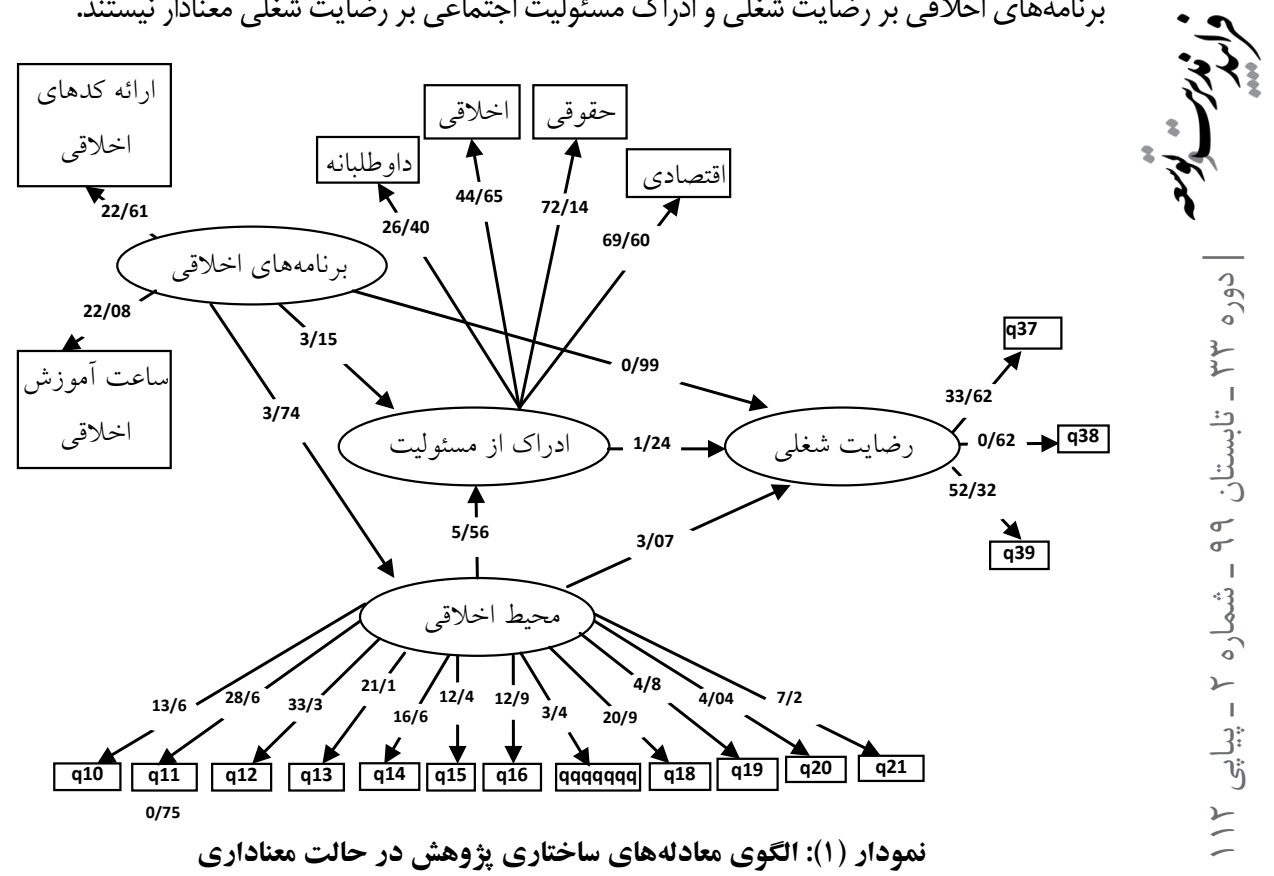

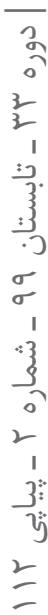

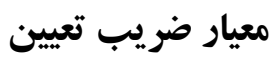

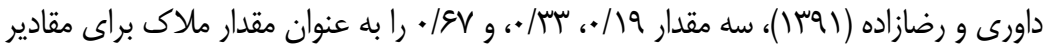

ضعيف، متوسط، و قوى ضريب تعيين معرفى مى كنند. بنابراين، با توجه به نمودار (Г)، ضريب تعيين

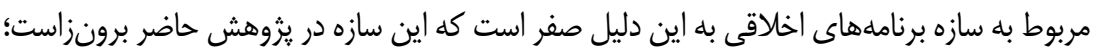
اما در مورد سازههاى درونزاى محيط اخلاقى، ادراك مسئوليت اجتماعى، و رضايت شغلى، بلهترتيب برابر با آ//، •ه/ •، و وس//• محاسبه مىشود كه نشان از مناسب بودن اين معيار دارد. نياز به اشاره 
است كه اين معيار از راه به توانِ دو رساندن ضريب مسير بهدست مىآيد. هرجه مقدار ضريب تعيين

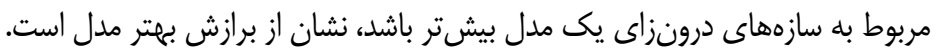

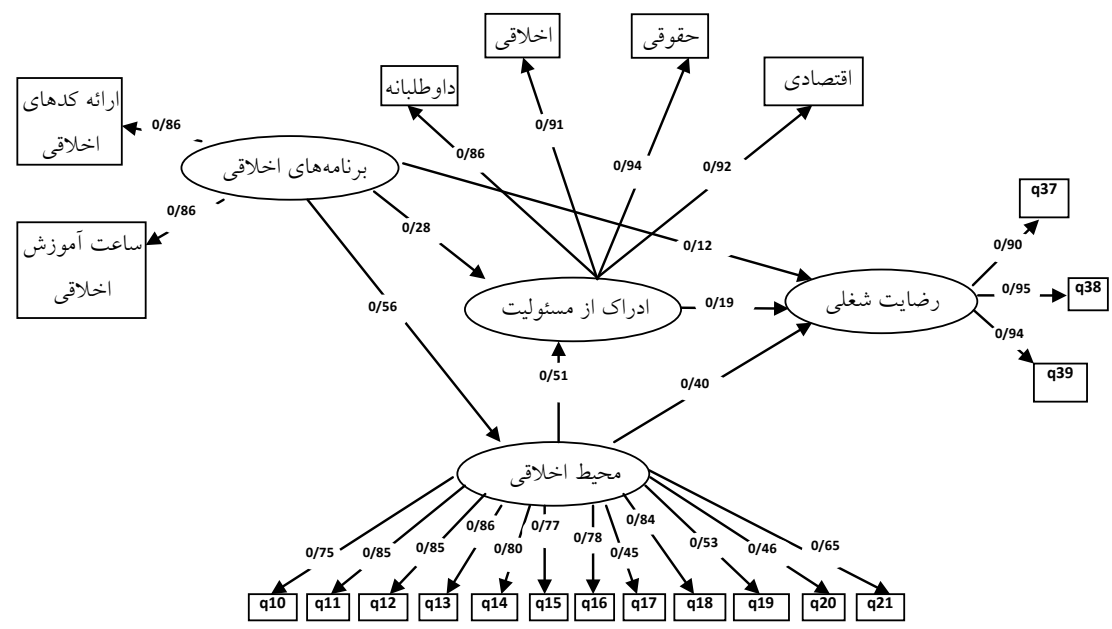

نمودار (ץ): الكوى معادلههاى ساختارى بثزوهش در حالت استاندارد

\section{معيارهاى ارزيابى برازش كلى مدل'}

همان گونه كه در نمودارهاى (I) و (Y) مشاهده مىشود، مقدار ضريب مسير مربوط به فرضيه يك، تاثير برنامه اخلاق بر محيط اخلاقى برابر با وه/٪ محاسبه مىشود. با توجه به مقدار عدد

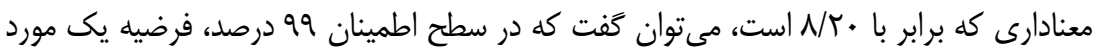
يذيرش است. براى فرضيه دو، يعنى تاثير برنامه اخلاقى بر ادراك از مسئوليت اجتماعى، ضرايب

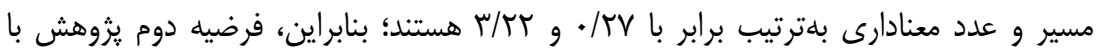
ضريب اطمينان 99 درصد مورد يذيرش است. ضريب مسير و عدد معنادارى براى فرضيه سه،

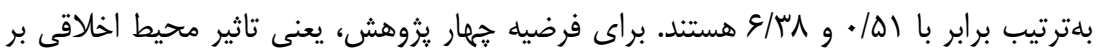

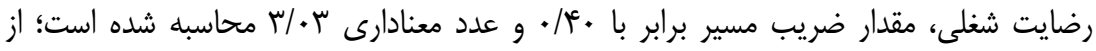
اينرو، فرضيه جهار يزوهش با اطمينان و9 درصد مورد يذيرش است. براى فرضيه ينج يعنى تاثير

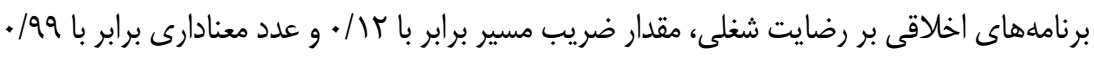


محاسبه شده است؛ با توجه به اين كه عدد معنادارى از مقدار عه/ا كمتر است، بنابراين فرضيه

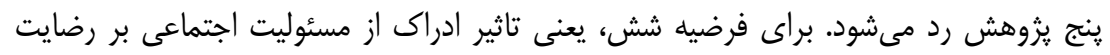

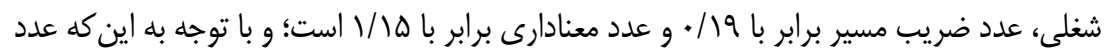

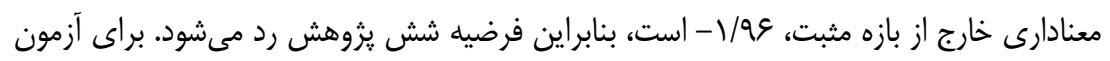

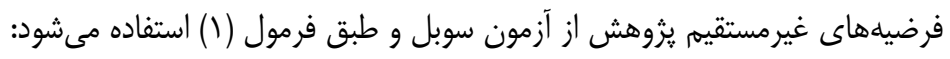

$$
\text { Z-value }=\frac{a \times b}{\sqrt{\left(b^{1} \times s_{a}^{2}\right)+\left(a^{1} \times s_{b}^{2}\right)+\left(s_{a}^{2} \times s_{b}^{2}\right)}}
$$

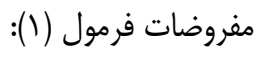

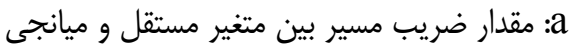

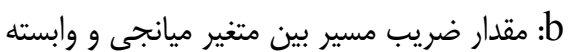

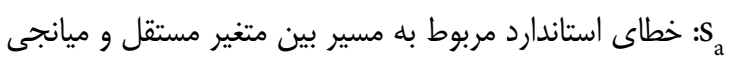

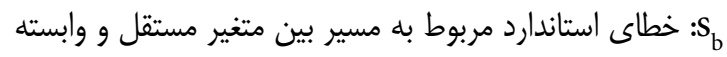

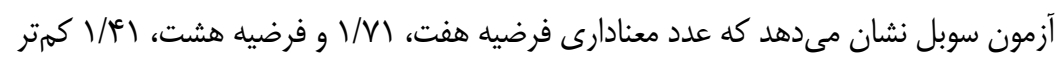

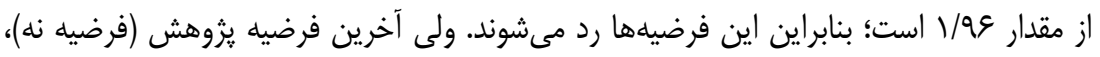

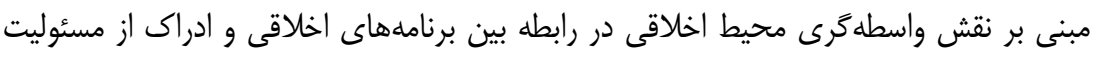

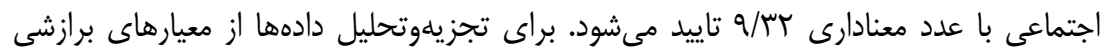

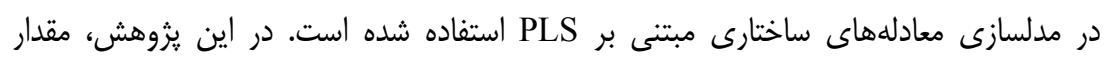

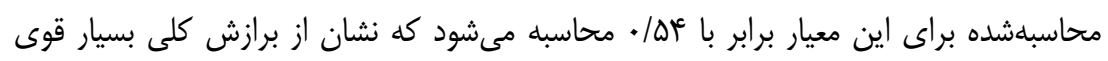

$$
\text { است؛ اين مقدار طبق فرمول (ז) بهدست مى آيد: }
$$

Gof $=\sqrt{{\text { communalities } x R_{2}}}$

Gof $=\sqrt{0 / 735 \times 0 / 4}=\sqrt{0 / 294}=0 / 54$

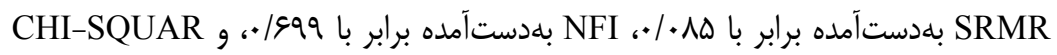

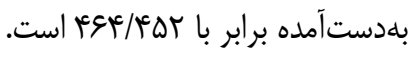


جدول f. نتايج آزمون فرضيههاى يزوهش

\begin{tabular}{|c|c|c|c|c|c|c|}
\hline 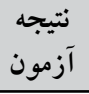 & معنادارى & اثر كل & غير مستقيم & 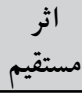 & فرضيه ها & 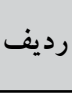 \\
\hline تاييد & $N / \cdot r$ & $\cdot / 09$ & $\ldots$ & $\cdot 109$ & برنامه اخلاقى بر محيط اخلاق تأثير مثبت دارد. & 1 \\
\hline تاييد & $r / r T$ & $\cdot / T V$ & $\ldots$ & $\cdot / T V$ & برنامه اخلاقى بر ادراك از مسئوليت اجتماعى مثبت دارد. & r \\
\hline تاييد & $9 / \pi r$ & $\cdot / 01$ & $\ldots$ & $\cdot / 01$ & محيط اخلاقى بر ادراى از مسئوليت اجتماعى مثبت دارد. & r \\
\hline تاييد & $r / \cdot r$ & $\cdot / 4$ & $\ldots$ & $\cdot / 4$ & محيط اخلاقى بر رضايت شغلى تأثير مثبت دارد. & r \\
\hline رد & $\cdot / 99$ & $\cdot / 1 r$ & $\ldots$ & $\cdot / r$ & برنامه اخلاقى بر رضايت شغلى تأثير مثبت دارد. & Q \\
\hline رد & $1 / 10$ & $\cdot / 19$ & $\ldots$ & $\cdot / 19$ & ادراك از مسئوليت اجتماعى بر رضايت شغلى مثبت دارد. & 4 \\
\hline נد & $1 / N 1$ & $\cdot / \mathrm{VV}$ & $\cdot / \cdot 0$ & $\cdot / r$ & اجتماعى بر رضامه اخلاقى از راه ادراك از مغلى تأثير مثبت دارد. & V \\
\hline رد & $\mid / 41$ & $\cdot / 41$ & $\cdot / \cdot 1$ & $\cdot / 4$ & اجتماعى بر رضالقى از راه ادراك أنير مثبت مسئوليت & $\wedge$ \\
\hline تاييد & $9 / \mu \mathrm{T}$ & $\cdot / \Delta \wedge$ & $\cdot / 19$ & $\cdot / r V$ & 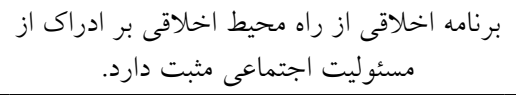 & 9 \\
\hline
\end{tabular}

\section{بحث و نتيجه كيرى}

شكل (T)، اعداد معنادارى و ضرايب مسير مربوط به مدل نهايى ثُوهش را نشان مىدهد.

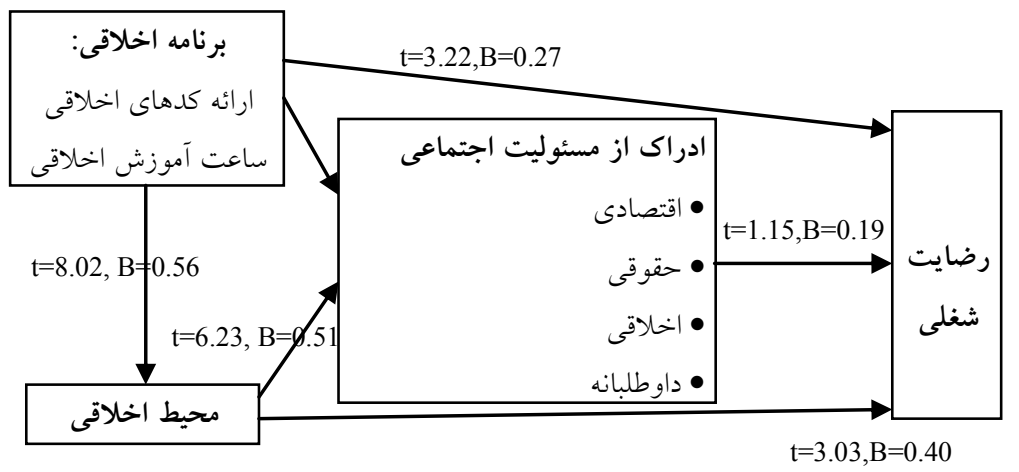

شكل r: مدل مفهومى نهايع بهدست آمده از نرمافزار PLS.03 
هدف از يزوهش حاضر، بررسى تاثير برنامهها و محيط اخلاقى از راه ادراك مسئوليت اجتماعى

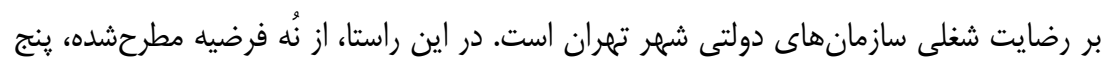

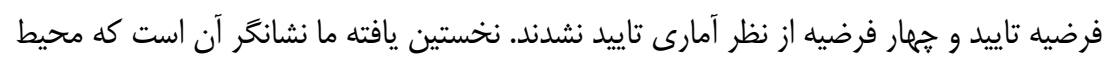

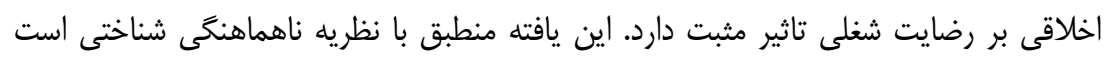

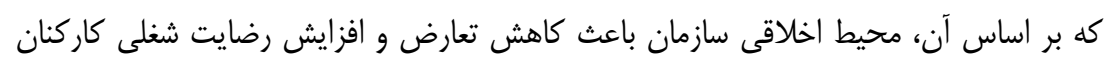

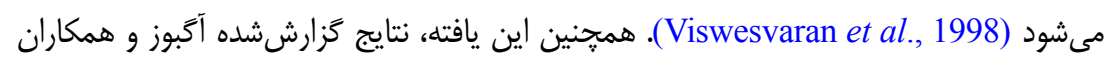

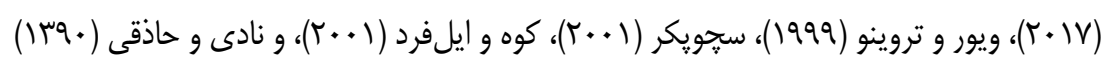

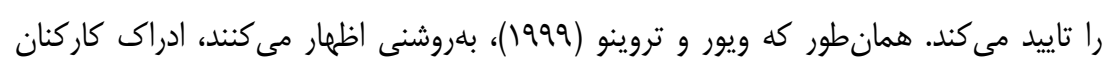

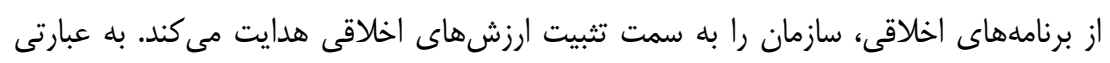

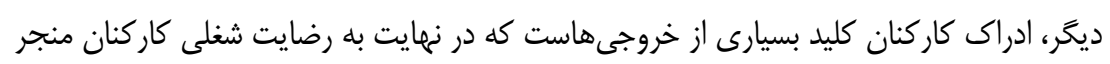

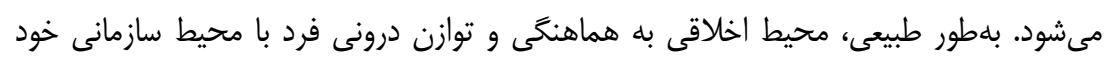

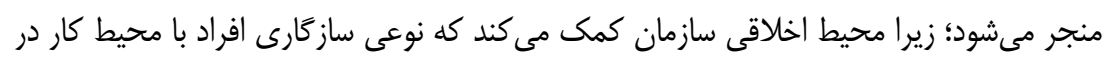

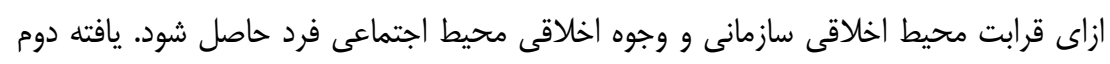

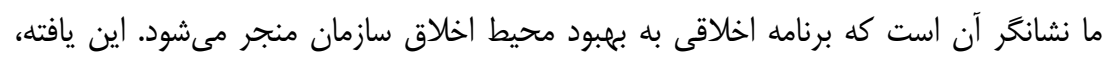

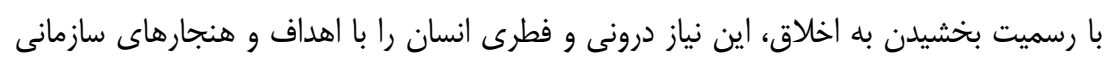

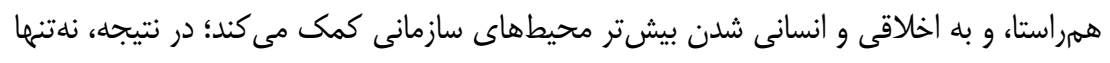

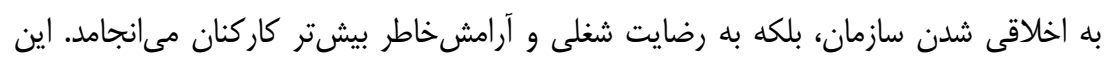

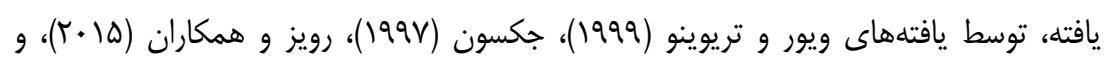

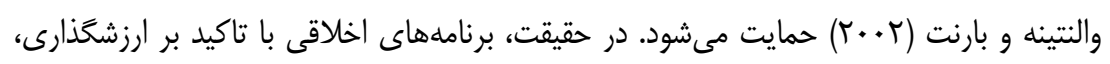

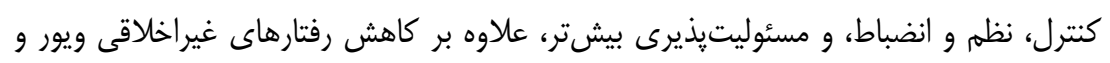

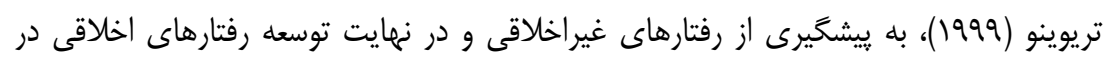
سازمان منجر مىشوند. منطبق بر نتايج، برنامه اخلاقى بر ادراك از مسئوليت اجتماعى سازمان تاثير مثبت دارد. اين

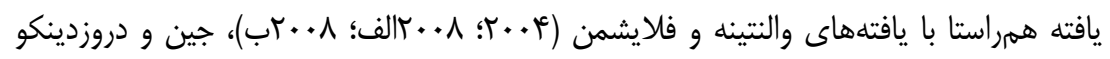

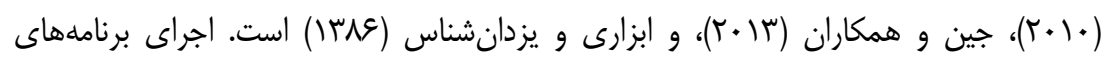

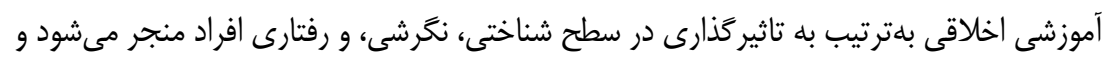

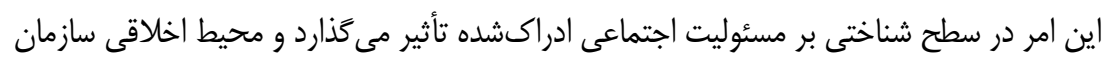

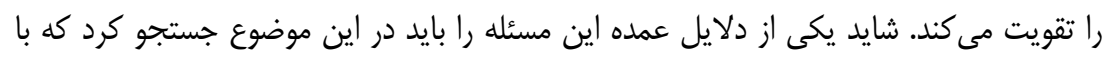


اجراى برنامههاى رسمى اخلاق در سطح سازمان، موضوع اخلاق از يكى مسئله شخصى و فردى

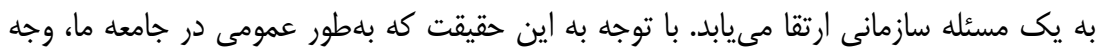

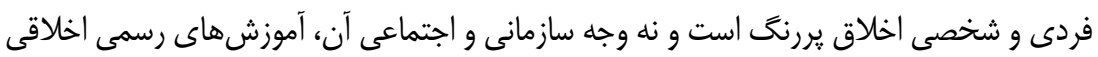
علاوه بر اين كه به احساس ارتقاى محيط اخلاقى سازمان منجر مىشوند، به ارتقاى ادراك كاركنان

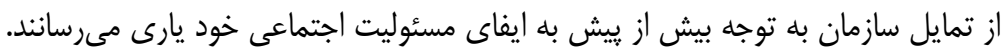
يافته جهارم اين يزوهش، نشانكر آن است كه در جامعه مورد مطالعه، محيط اخلاقى بر ادراك باك

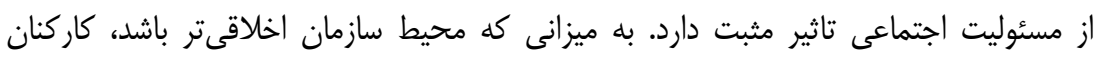
سازمان ادراك مثبتترى از تحقق مسئوليت اجتماعى سازمان دارند. به بيانى ديخر، محيط اخلاقى إنى

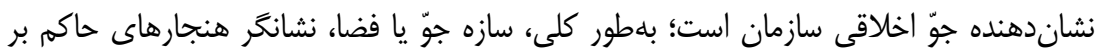

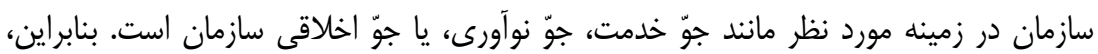

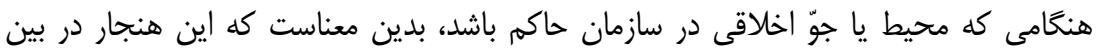

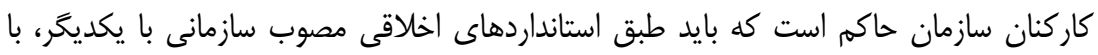

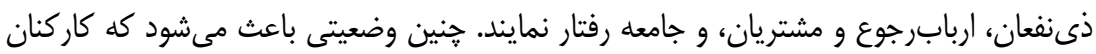

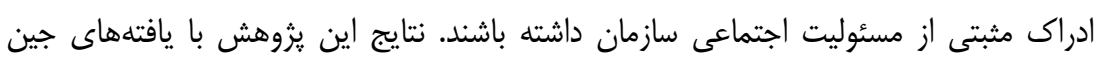

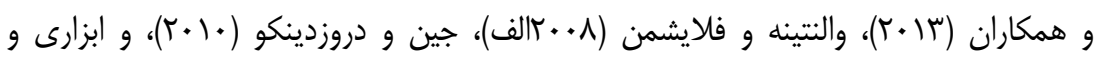
يزدان شناس (عNى (1) همراستاست.

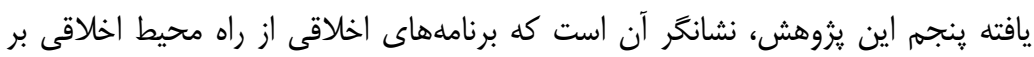

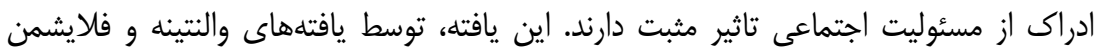

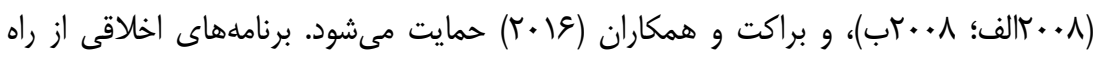
محيط اخلاقى بر ادراك از مسئوليت اجتماعى تاثير مثبت دارند. اخلاقى شدن محيط سازمان به

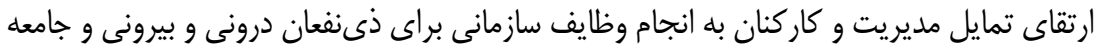

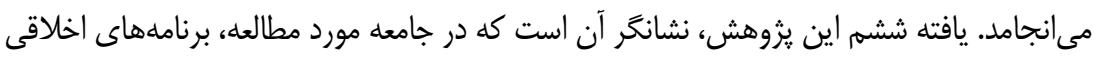

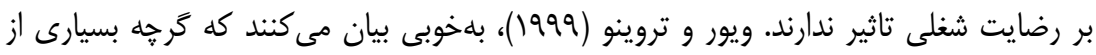

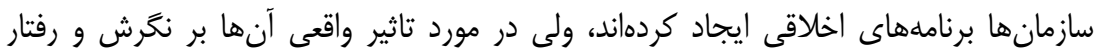

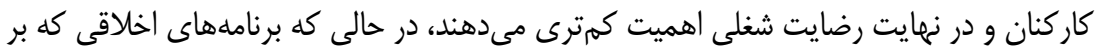

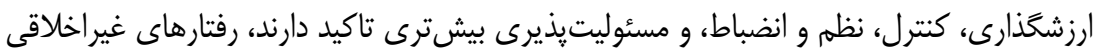

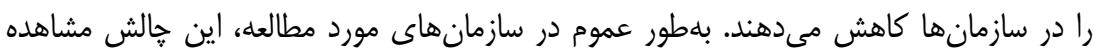

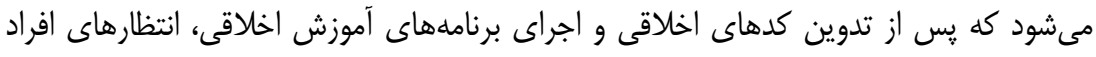


ارتقا مى يابند و קهبسا براى مدتى كوتاه، كاركنان از اين كه در اساس خنين رويكردى توسعه خلاق

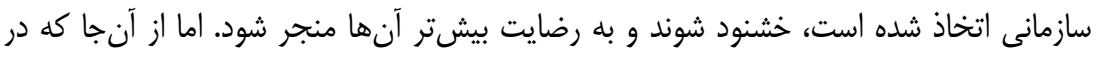

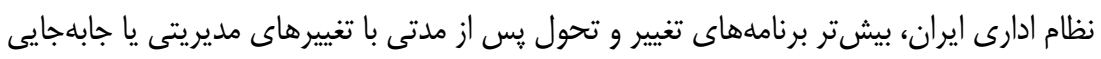
دولتها، به فراموشى سيرده مىشوند، در نتيجه، سازوكارها و ضمانت اجرايى برنامهها تضعيف

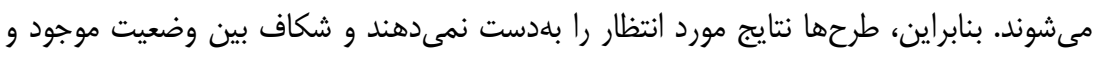

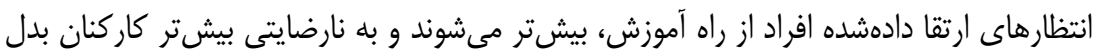

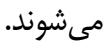
يافته هفتم يزوهش، نشانكر آن است كه ادراك از مسئوليت اجتماعى بر رضايت شغلى تاثير

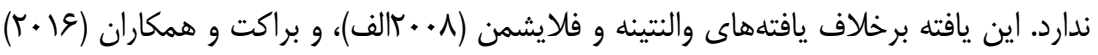
است كه رابطه مثبت بين مسئوليت اجتماعى سازمان بر رضايت شغلى كاركنان را مورد تاكيد قرار

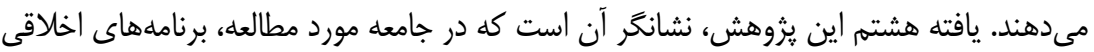

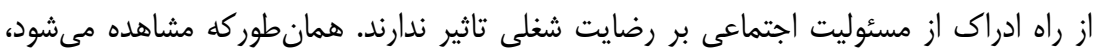

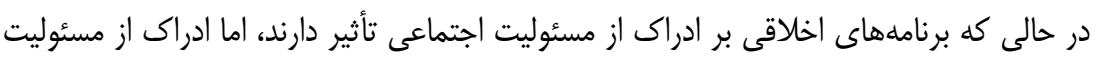

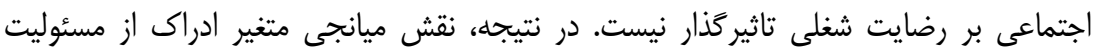

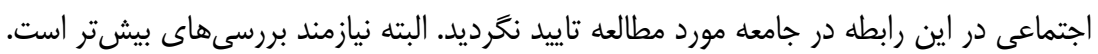

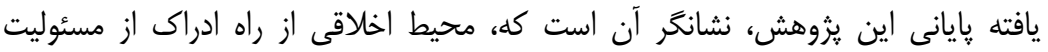

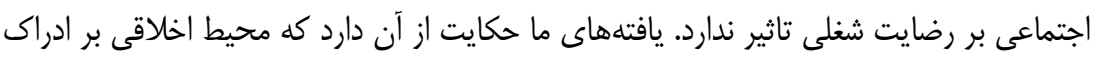

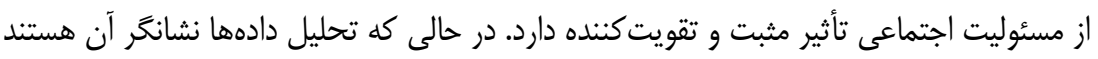

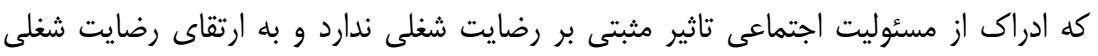

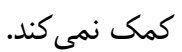

با توجه به اهميت برنامههاى اخلاقى و تاثير آن بر محيط اخلاقى، به سازمان ها توصيه مىشود كه با ايجاد يك برنامه اخلاقى، اخلاق را در محيط كار، مديريت و نهادينه كنند. به مديران توصيه

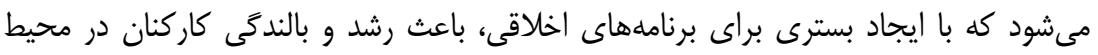

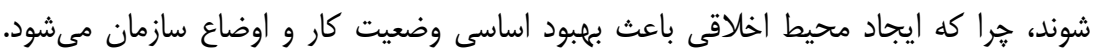
سازمانها مىتوانند با ايجاد محيط اخلاقى، اخلاق را در محيط كار مديريت كنند. بنابراين، ايجاد

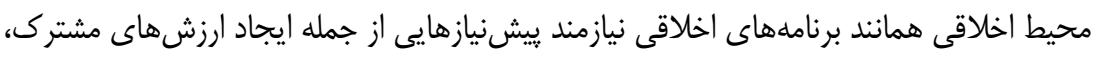

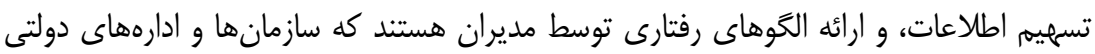

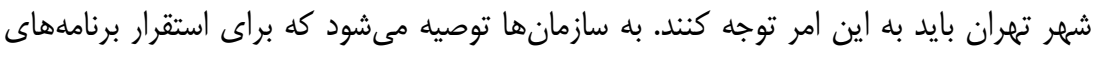


اخلاقى و روابط انسانى، از رويكردهاى مختلفى استفاده كنند؛ مانند آموزش برنامههاى اخلاقى.

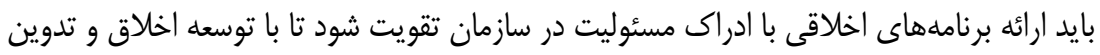

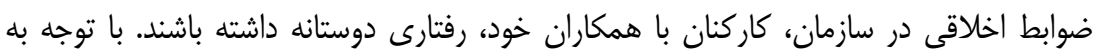

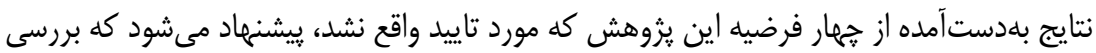

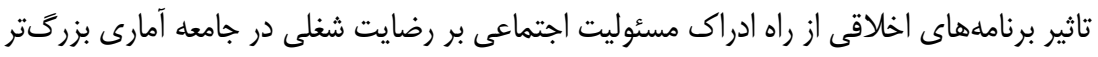

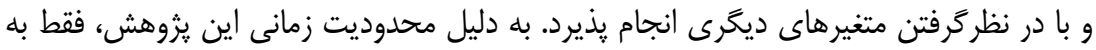

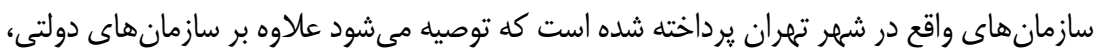
در سازمانها خصوصى نيز بررسى اين روابط مورد توجه و مطالعه قرار كيرد.

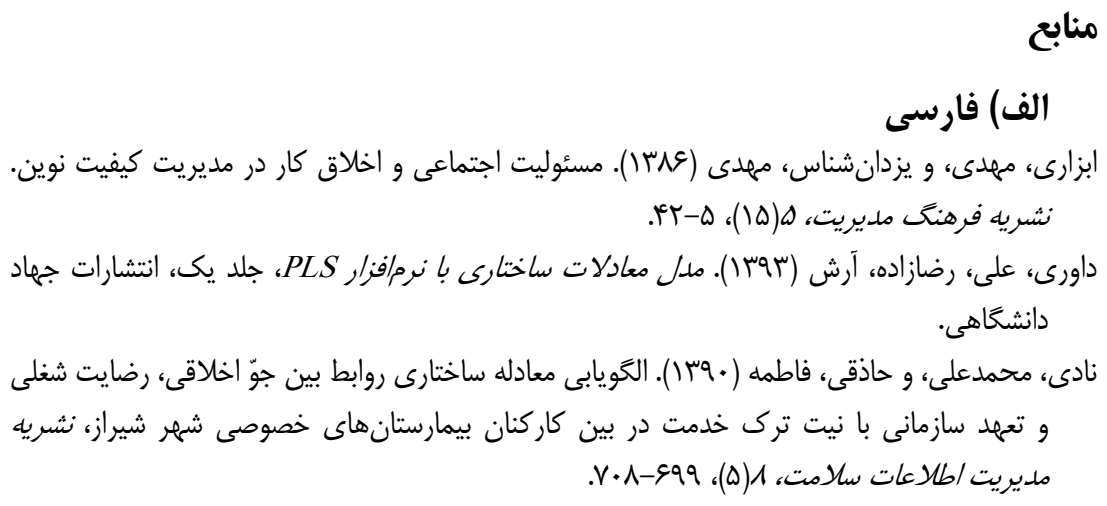

Adams, J. S., Tashchian, A., \& Shore, T. H. (2001). Codes of Ethics as Signals for Ethical Behavior. Journal of Business Ethics, 29(3), 199-211.

Agbozo, G. K., Owusu, I. S., Hoedoafia, M. A., \& Atakorah, Y. B. (2017). The Effect of Work Environment on Job Satisfaction: Evidence from the Banking Sector in Ghana. Journal of Human Resource Management, 5(1), 12-18.

Arnaudov, K. \& Koseska, E. (2012). Business Ethics and Social Responsibility in Tourist Organizations in Terms of Changing Environment. Procedia-Social and Behavioral Sciences, 44(1), 387-397.

Asrar-ul-Haq, M., Kuchinke, K. P., \& Iqbal, A. (2017). The Relationship between Corporate Social Responsibility, job Satisfaction, and Organizational Commitment: Case of Pakistani Higher Education. Journal of Cleaner 
Production, 142(1), 2352-2363.

Barakat, S. R., Isabella, G., Gama Boaventura, J. M., \& Mazzon, J. A. (2016). The Influence of Corporate Social Responsibility on Employee Satisfaction, Management Decision, 54(9), 2325-2339.

Branco, M. C., \& Rodrigues, L. L. (2006). Corporate Social Responsibility and Resource-Based Perspectives. Journal of Business Ethics, 69(2), 111-132.

Carroll, A. B. (1979). A Three-Dimensional Conceptual Model of Corporate Performance. Academy of Management Review, 4(4), 497-505.

Crespo, A. H., \& Del Bosque, I. R. (2005). Influence of Corporate Social Responsibility on Loyalty and Valuation of Services. Journal of Business Ethics, 61(4), 369-385.

Daehlen, M. (2008). Job Satisfaction and Job Values among Beginning Nurses: A Questionnaire Survey. International Journal of Nursing Studies, 45(12), 1789-1799.

Elçi, M., \& Alpkan, L. (2009). The Impact of Perceived Organizational Ethical Climate on Work Satisfaction. Journal of Business Ethics, 84(3), 297-311.

Fornell, C., \& Larcker, D. F. (1981). Evaluating Structural Equation Models with Unobservable Variables and Measurement Error. Journal of Marketing Research, 18(1), 39-50.

Halinen, A., \& Jokela, P. (2016). Exploring Ethics in Business Networks: Propositions for Future Research Extending the Business Network Approach (pp. 333-356): Springer.

Hassan, S. (2015). The Importance of Ethical Leadership and Personal Control in Promoting Improvement-Centered Voice among Government Employees. Journal of Public Administration Research and Theory, 25(3), 697-719.

Herrbach, O., \& Mignonac, K. (2007). Is Ethical P-O Fit Really Related to Individual Outcomes? A Study of Management-Level Employees. Business \& Society, 46(3), 304-330.

Jackson, K. T. (1997). Globalizing Corporate Ethics Programs: Perils and Prospects From the Universities to the Marketplace: The Business Ethics Journey (17-25): Springer.

Jaramillo, F., Mulki, J. P., \& Solomon, P. (2006). The Role of Ethical Climate on Salesperson's Role Stress, Job Attitudes, Turnover Intention, and Job Performance. Journal of Personal Selling \& Sales Management, 26(3), 271-282.

Jin, K. G., \& Drozdenko, R. G. (2010). Relationships among Perceived Organizational Core Values, Corporate Social Responsibility, Ethics, and Organizational Performance Outcomes: An Empirical Study of Information Technology Professionals. Journal of Business Ethics, 92(3), 341-359. 
Jin, K. G., Drozdenko, R., \& DeLoughy, S. (2013). The Role of Corporate Value Clusters in Ethics, Social Responsibility, and Performance: A Study of Financial Professionals and Implications for the Financial Meltdown. Journal of Business Ethics, 112(1), 15-24.

Kakabadse, N. K., \& Rozuel, C. (2006). Meaning of Corporate Social Responsibility in a Local French Hospital: A Case Study. Society and Business Review, 1(1), 77-96.

Kaptein, M. (2009). Ethics Programs and Ethical Culture: A Next Step in Unraveling their Multi-Faceted Relationship. Journal of Business Ethics, 89(2), 261-281.

Kaptein, M. (2011). Understanding Unethical Behavior by Unraveling Ethical Culture. Human Relations, 64(6), 843-869.

Kaptein, M., \& Schwartz, M. S. (2008). The Effectiveness of Business Codes: A Critical Examination of Existing Studies and the Development of an Integrated Research Model. Journal of Business Ethics, 77(2), 111-127.

Koh, H. C., \& El'Fred, H. (2001). The Link between Organizational Ethics and Job Satisfaction: A Study of Managers in Singapore. Journal of Business Ethics, 29(4), 309-324.

Koh, H. C., \& El'fred, H. (2004). Organisational Ethics and Employee Satisfaction and Commitment. Management Decision, 42(5), 677-693.

Koonmee, K., Singhapakdi, A., Virakul, B., \& Lee, D.-J. (2010). Ethics Institutionalization, Quality of Work Life, and Employee Job-Related Outcomes: A Survey of Human Resource Managers in Thailand. Journal of Business Research, 63(1), 20-26.

Lu, K.-Y., Chang, L.-C., \& Wu, H.-L. (2007). Relationships between Professional Commitment, Job Satisfaction, and Work Stress in Public Health Nurses in Taiwan. Journal of Professional Nursing, 23(2), 110-116.

Mandhachitara, R. \& Poolthong, Y. (2011). A Model of Customer Loyalty and Corporate Social Responsibility. Journal of Services Marketing, 25(2), $122-133$

Meriac, J. P., \& Gorman, C. A. (2017). Work Ethic and Work Outcomes in an Expanded Criterion Domain. Journal of Business and Psychology, 32(3), 273-282.

Neubert, J. C., Mainert, J., Kretzschmar, A., \& Greiff, S. (2015). The Assessment of 21st Century Skills in Industrial and Organizational Psychology: Complex and Collaborative Problem Solving. Industrial and Organizational Psychology, $8(2), 238-268$.

Ruiz, P., Martinez, R., Rodrigo, J., \& Diaz, C. (2015). Level of Coherence among Ethics Program Components and its Impact on Ethical Intent. 
Journal of Business Ethics, 128(4), 725-742.

Schwepker Jr, C. H. (2001). Ethical Climate's Relationship to Job Satisfaction, Organizational Commitment, and Turnover Intention in the Salesforce. Journal of Business Research, 54(1), 39-52.

Shafer, W. E. (2015). Ethical Climate, Social Responsibility, and Earnings Management. Journal of Business Ethics, 126(1), 43-60.

Treviño, L. K., Butterfield, K. D., \& McCabe, D. L. (1998). The Ethical Context in Organizations: Influences on Employee Attitudes and Behaviors. Business Ethics Quarterly, 8(3), 447-476.

Valentine, S., \& Barnett, T. (2002). Ethics Codes and Sales Professionals' Perceptions of their Organizations' Ethical Values. Journal of Business Ethics, 40(3), 191-200.

Valentine, S., \& Fleischman, G. (2004). Ethics Training and Businesspersons' Perceptions of Organizational Ethics. Journal of Business Ethics, 52(4), 391-400.

Valentine, S., \& Fleischman, G. (2008a). Ethics Programs, Perceived Corporate Social Responsibility and Job Satisfaction. Journal of Business Ethics, 77(2), 159-172.

Valentine, S., \& Fleischman, G. (2008b). Professional Ethical Standards, Corporate Social Responsibility, and the Perceived Role of Ethics and Social Responsibility. Journal of Business Ethics, 82(3), 657-666.

Viswesvaran, C., Deshpande, S. P., \& Joseph, J. (1998). Job Satisfaction as a Function of Top Management Support for Ethical Behavior: A Study of Indian Managers. Journal of Business Ethics, 17(4), 365-371.

Vlachos, P. A., Tsamakos, A., Vrechopoulos, A. P., \& Avramidis, P. K. (2009). Corporate Social Responsibility: Attributions, Loyalty, and the Mediating Role of Trust. Journal of the Academy of Marketing Science, 37(2), 170-180.

Weaver, G. R., \& Treviño, L. K. (1999). Compliance and Values Oriented Ethics Programs: Influences on Employees' Attitudes and Behavior. Business Ethics Quarterly, 9(2), 315-335.

Weaver, G. R., Trevino, L. K., \& Cochran, P. L. (1999). Corporate Ethics Programs as Control Systems: Influences of Executive Commitment and Environmental Factors. Academy of Management Journal, 42(1), 41-57.

Willem, A., Buelens, M., \& De Jonghe, I. (2007). Impact of Organizational Structure on Nurses' Job Satisfaction: A Questionnaire Survey. International Journal of Nursing Studies, 44(6), 1011-1020.

Yang, F. H., \& Chang, C. C. (2008). Emotional Labour, Job Satisfaction and Organizational Commitment Amongst Clinical Nurses: Questionnaire Survey. International Journal of Nursing Studies, 45(6), 879-887. 